\title{
Improvement of water use efficiency on potato production
}

\section{2- Calculated crop coefficient for potato crop under different irrigation regimes}

\author{
*Abdel-Ati Y.Y., **Abdelreheem H. A.,*Abdelmageed Y.T., \\ *EImazny M.Y. and Khaled. M. Farghaly \\ *Agric.faculty, Minia univ., Minia - Egypt. \\ **Water Management Res. Ins., National Water Research Center.
}

\begin{abstract}
Two field experiments were carried out at Mallawi requirements research station ElMinia Governorate, Egypt; Water Management Research Institute - National Water Research Center during 2012 and 2013 seasons.

The aim of this investigation is to evaluate the effect of the different irrigation regimes and potassium fertilization rates on crop coefficient of potato. Also it evaluate and compare the potential evapotranspiration $\left(\mathrm{ET}_{\mathrm{p}}\right)$ with actual water requirement under El-Minia Governorate conditions. The experiment included five treatments of irrigation regimes (A) and four treatments of potassium fertilization (B) with three replicates so that the experiment was arranged in a split plot design. The irrigation regime treatments were treationial irrigation (the farmers practes, $100 \%, 90 \%, 80 \%$ and $70 \%$ of field capcity). Potassium rates was applied in a form of potassium sulphate $\left(48 \% \mathrm{~K}_{2} \mathrm{O}\right)$ at rate $200 \mathrm{~kg} / \mathrm{fed} .\left(\mathrm{b}_{1}\right), 100 \mathrm{~kg}$ $\mathrm{K}_{2} \mathrm{O} / \mathrm{fed}$. + potasine (Biofertilizer) at rate 6 liters/fed $\left(\mathrm{b}_{2}\right), 100 \mathrm{~kg} / \mathrm{fed}$. + potasine (Biofertilizer) at rat 6 liters/fed. + potassium foliar $\left(36 \% \mathrm{~K}_{2} \mathrm{O}\right)$ at rate 2 liters/fed. $\left(\mathrm{b}_{3}\right)$ and Potassium (biofertilizer) at rate 6 liters/fed $\left(\mathrm{b}_{4}\right)$.

These results indicated that the first irrigation treatment where plants irrigated with conventinal irrigation had the highest value of actual consumptive use (daily and seasonal). This was due to the decrease in the value of tension moisture of the first treatment which led to increasing the water actual consumptive use. While, the fifth irrigation treatment for plants irrigated until $70 \%$ of field capacity had the lowest value of actual consumptive use (daily and seasonal). The application of Potassium fertilization caused a slight decrease in daily, monthly and seasonal actual evapotranspiration $\left(\mathrm{ET}_{\mathrm{a}}\right)$, in both seasons. Modified Penman and modified Blaney \& Criddle gave high average values for potential evapotranspiration $\left(\mathrm{ET}_{\mathrm{p}}\right)$ (63.24 and $56.50 \mathrm{~cm} / \mathrm{season}$ ) while radation method and pan method gave less average values (53.99 and $49.11 \mathrm{~cm} /$ season) for the two studied seasons respectively. The actual values of evapotranspiration were less than those computed by climatological equations. This is due to the estimated factors in these equations.

The average values of potential evapotranspiration $\left(\mathrm{ET}_{\mathrm{p}}\right)$ for the two studied seasons, by modified Blaney \& Criddle and radation method were the nearest values to general average (+1.41 and $-3.09 \%$ respectively). While, the farthest values to general average were obtained by modified Penman and Pan method ( +13.52 and $-11.85 \%$ respectively). Kc average were $0.76,0.72,0.71,0.70$ and 0.68 for $A_{1}, A_{2}, A_{3}, A_{4}$ and $A_{5}$ under all subtreatments respectively. Modified Blaney \& Criddle was the nearest to the actual consumptive use.
\end{abstract}

Therefore, recommended for calculating the potential evapotranspiration using modified Blaney \& Criddle or radiation method for potato plants which grow under El-Minia conditions and other corresponding conditions.

Key words: Water Use Efficiency, Potato Production, crop coefficient, irrigation regimes. 


\section{INTRODUCTION}

Water is fast becoming an economically scarce resource in many areas of the world, especially in arid and semi-arid regions. In Egypt, there are many plans for increasing cultivable land and agriculture production to overcome the problems of food security. In this regard, soil moisture is one of the most important factors which influence the yield and quality of crops as affect the chemical, biological and physical conditions of the soil. Available water in the soil is essential for the life and function of plants. Water is necessary for growth, nutrient, absorption, transpiration, biological reactions and many other life activities. Therefore, water requirements should be achieved to reach a well controlled scientific use of water. In all countries, all over the world, water is considered a limiting factor in agricultural expansion.

Measuring or calculating evapotranspiration rate could be achieved by many motheds such as soil moisture depletion method and using the meterological data throughout the growth seasons. The later method leads to evaluate an imperial constant, for specific vegetation grown in a particular location, which can be used afterwards as an index for direct calculation of evapotranspiration. For many years, certain types of climatological data such as temperature, precipitation, solar radiation, wind speed...etc. have been correlated.

The determination of crop coefficient $(\mathrm{Kc})$ can be used to relate reference crop evapotranspiration $\left(\mathrm{ET}_{\mathrm{p}}\right)$ to maxium crop evaportranspiration when water supply fully meets water requirements of the crop. Rijtema (1966) stated that there are many methods to calculate the potential evapotranspiration. Some of these methods or formulas give reasonable accuracy under certain climatological conditions. Other methods agree only with observed values if corrections for time $\log$ and wind speed are applied. The value of crop coefficient in potato depended on the growth stage of the plant, the location of collected data and methods which used to calculate the reference evapotransiration Doorenhbos and Pruitt (1975) stated that Blaney - Criddle method may be used when temperature data are the only available measured weather data. They reported that the radiation method is more reliable than the presented Blaney \& Criddle approach. In equatorial zones, on a small island or at high altitudes, the radiation method may be more reliable even if measured sunshine or cloudness data are not available. Solar radiation maps were prepared for most locations in the world, and they provide the necessary solar radiation data. Also found that stated that Blaney $\&$ Criddle method may be used when temperature data were the only available measured weather data. They reported that the radiation method was more reliable than the presented Blaney \& Criddie approach. In equatorial zone, on a small island or at high altitudes, the radiation method might be more reliable even if measured sunshine or cloudless data were not available. Solar radiation maps were prepared for most locations in the world and they provided the necessary solar radiation data. They also pointed out that crop water requirements are normally expressed by the rate of evapotanspiration (ET) in $\mathrm{mm} / \mathrm{day}$ or $\mathrm{mm} /$ period. The level of ET has been shown to be related to evaporative demand of air which could be expressed as refernce evapotranspiration and added calculated the crop evapotranspiration by using the following formula:

Where:

$$
\mathrm{ET}_{\mathrm{c}}=\mathrm{Kc}_{\mathrm{XET}}
$$

$$
\begin{aligned}
& \mathrm{ET}_{\mathrm{c}}=\text { Crop evapotranspiration } \\
& \mathrm{Kc}=\text { Crop coefficient } \\
& \mathrm{ET}_{\mathrm{o}}=\text { Reference crop evapotranspiration }
\end{aligned}
$$

They added that the determination of crop coefficient $(\mathrm{Kc})$ could be used as reference crop evapotranspiration $\left(\mathrm{ET}_{\mathrm{o}}\right)$ to maximum crop evapotranspiration when water supply full met water requirements of the crop. 


\section{Improvement of water use efficiency on potato production \\ 2- Calculated crop coefficient for potato crop under different irrigation regimes}

Van der Molen (1976) stated that crop evapotranspiration $\left(\mathrm{ET}_{\mathrm{c}}\right)$ was less than potential evapotranspiration $\left(\mathrm{ET}_{\mathrm{p}}\right)$ for short grass due to:

a. Moisture shortage.

b. The inadequate covering of the crop (e.g., young beets).

c. End of growth period (e.g. ripening cerals).

Thus, the evapotransiration of arable land was often less than that of grass land. On the other hand, $\mathrm{ET}_{\mathrm{p}}$ of short grass was less than $\mathrm{ET}_{\mathrm{p}}$ of tall crops when they were provided with irrigation water. Wright (1981) defined reference crop ET, as being equal to daily alfalfa ET when the crop occupies an extensive surface, is actively growing standing erect and at least $20 \mathrm{~cm}$ tall and well watered soil water availability. Ferdous et al., (1985) indicated that crop coefficient values obtained from ratios between actual evapotranspiration of potato and potential (ET) of Alfalfa at the different growth stages were 0.3 at emergence stage, 1.23 during full cover stage and 0.48 at maturity. Doorenbos and Kassam (1986) reported that potatoes crop coefficient changed with growth season as 0.4 to 0.5 during establishment, 0.7 to 0.8 during early vegetation, 1.05 to 1.2 during stolonization, 0.85 to 0.95 during yield formation and 0.7 to 0.75 during ripening. Vermiren and jobling (1986) reported that the accuracy of determined ET crop depends on type of climatic data available, and the accuracy of the method chosen to estimate $\mathrm{ET}_{\mathrm{o}}$. They also concluded that Penman and radiations methods are best for near estimates over short periods of about 10 days. The pan evaporatin method is often the second choice. but can be superior with excellent sitting and light winds. Also, they reported that Blaney \& Criddle method is the best for a period of one month. Eid et al. (1987) reported that the average crop coefficient was 0.78 for winter potatoes while the average crop coefficient was 0.77 for that growing in the summer. Semaika and Rady (1987) recommended any of modifield Blaney \& Criddle or the radiation formulas for estimating evapotranspiration of wheat, field beans and clover for Giza area - Egypt, with the average crop coefficient due highest accuracy. Oweis et al. (1988) found that the potato crop coefficient changed in response to crop growth stages $<0.5$ during plant emergence stage, to about 0.8 at maximum crop leaf area then decreased to be $<0.5$ just before harvesting stage. Stansell et al. (1990) found that crop coefficient initially incrased then decreased with the plant age, when pan evaporation method, under three soil moisture tension was used. Ali (1993) showed that values of potato crop coefficient estimated by using Penman formula and actual evapotrnspiration rates were low at the initial stage, then increased to reach its maximum value at mid season stage (the period of tuberization), then asharp decrease in crop coefficince was observed at the end of the season. Seasonal crop coefficients were found to be 0.75 and 0.77 for summer and fall plantation. respectively. El-Naggar (1997) found that the calculated values of crop coefficient $(\mathrm{Kc})$, using actual evapotranspiration measured either gravimetrimetrically or by neutron probe and reference evapotranspiration determined by using Penman or Pan evaporation equations, were slightly differed at the same concerning periods, and under the same irrigation treatments $(600,450$ and $300 \mathrm{~mm} / \mathrm{season}$, respectiovely) The values of Kc were incrased with increasing the amounts of added irrigation water. The average values of potato Kc were 1.02, 0.92 and 0.64 for Kc Penman GM and 0.92, 0.87 and 0.65 for Kc Penman Np. While these values were; 0.95, 0.84 and 0.6 for Kc GM, and 0.85, 0.8 and 0.6 for Kc Pan - Np under the above-mentioned application rates of irrigation water. Allen et al., (1998) for $\mathrm{ET}_{\mathrm{r}}$ the crop coefficients for potatoes at different stages were $0.42,0.85,1.27$, and 0.57 for initial, crop development, reproductive and maturity stages, respectively. These values are similar to the FAO 56 values, except during the reproductive stage. Omar and Eid (1999) compred 6 ET formula with the measured ET values in Bahtim (South Delta), they found that Doorenbos - Pruitt method had 
Abdel-Ati Y.Y. et al.

the best estimation followed by the evaporation pan and then the Penman - Monteith method. The fourth one, in order, was modified, Penman.

They found also that the values of Penman - Montieth method and the modified Penman, introduced a new method which gives estimates of $\mathrm{ET}_{\mathrm{o}}$ near to those of the best method of Doorenbos- Pruitt. Sahin et al. (2007) determined crop coefficients for sugarbeet and potato under cool season semiarid climate in Turkey. From May to October in 2003 and $2004, \mathrm{ET}_{\mathrm{c}}$ was measured by the water balance approach, and the $\mathrm{ET}_{\mathrm{r}}$ by FAO PenmanMonteith. Seasonal $\mathrm{ET}_{\mathrm{c}}$ was $493 \mathrm{~mm}$ for sugar beet and $445 \mathrm{~mm}$ for potato. The seasonal crop coefficient was 0.65 for sugarbeet, and 0.60 for potato. Daniel et al. (2013) study quantify and water consumption and the crop coefficients $(\mathrm{Kc})$ for the potato (Solanum tuberosum L.), in Seropedica, Rio de Janeiro (RJ), Brazil, under organic management and to simulate the crop evapotranspiration $\left(\mathrm{ET}_{\mathrm{c}}\right.$ ) using the Kc obtained in the field and the ones recommended by the food and Agriculture Organization (FAO). The water consumption was obtained through soil water balance, using TDR probes installed at $0.15 \mathrm{~m}$ and 0.30 deep. At the different stages of development, the Kc was determined by the ratio of ETc and reference evapotranspiration, obtained by Penman-Monteith FAO56. The crop coefficients obtained were $0.35,0.45,1.29$ and 0.63 . Abubaker et al., (2014) found that as experimentally evident, the weather conditions, water, soil characteristics and the agronomic techniques affect the crop growth and crop production. Yield components of potato were affected significantly by optimum irrigation treatment. There is a close agreement between the actually applied and the estimated water requirement for the potato crop, on the other hand Blaney \& Criddle method could be adopted in the semi-arid environment of Sudan, because it is simple and only required the data on temperature and day length. The optimum amount of water for the best growth, yield and quality of the potato crop at Waramli area environment ranges between 560 and $600 \mathrm{~mm} / \mathrm{season}$, to be applied in 8-10 irrigation, depending on the prevailing weather conditions. Also results showed that the growth parmeters and the yield were significantly response $(\mathrm{P}<0.05)$ to the seasonal water supply. The tuber yield was increased during the first season on the behalf of water supplied as compared to other.

The objective of the present work was evaluated the effect of the different irrigation regimes and potassium fertilization rates on crop coefficient of potato, evaluate and compare the potential evapotranspiration $\left(\mathrm{ET}_{\mathrm{p}}\right)$ equations with actual water requirement $\left(\mathrm{ET}_{\mathrm{a}}\right)$ under El-Minia Governorate conditions.

\section{MATERIALS AND METHODS}

Two field experiments were carried out for two seasons Autumn and winter of 2012 and 2013 seasons, at Mallawy, Water Requirements Research Station El-Minia Governorate; Water Management Research Institute - National Water Research Center. The present research was carried out to study the effect of irrigation system and different rates of potassium fertilization on water consumptive use, water applied and crop coefficient. The experimen included five irrigation regimes treatments $\left(\mathrm{A}_{1}\right)$ conventional irrigation by farmer practices, $\left(A_{2}\right)$ Irrigation until $100 \%$ of field capacity, $\left(A_{3}\right)$ irrigation until $90 \%$ of field capacity, $\left(\mathrm{A}_{4}\right)$ irrigation until $80 \%$ of field capacity and $\left(\mathrm{A}_{5}\right)$ irrigation until $70 \%$ of field capacity and four rates of potassium fertilization. Potassium rates was applied in a form of potassium sulphate $\left(48 \% \mathrm{~K}_{2} \mathrm{O}\right)$ at rate $200 \mathrm{~kg} / \mathrm{fed}\left(\mathrm{b}_{1}\right), 100 \mathrm{~kg} \mathrm{~K}_{2} \mathrm{O} / \mathrm{fed}$. + potasine (Biofertilizer) at rate 6 liters/fed $\left(b_{2}\right), 100 \mathrm{~kg} / \mathrm{fed}$. + potasine (Biofertilizer) at rate 6 liters/fed + potassium foliar $\left(36 \% \mathrm{~K}_{2} \mathrm{O}\right)$ at rate 2 liters/fed $\left(\mathrm{b}_{3}\right)$ and Potassium (biofertilizer) at rate 6 liters/fed $\left(b_{4}\right)$. So that the experiment was arranged in a split plot design. The treatments of irrigation regimes were distributed at random in the main plots. While, potassium treatments were distributed at random in the sub-plots. The recommened $\mathrm{N}$ fertilizer $(150 \mathrm{~kg} \mathrm{~N} / \mathrm{fed})$ were given in a form of ammonium sulphate $(20.6 \% \mathrm{~N}$ ) (at rate 50 ammonium sulphate $\mathrm{kg} / \mathrm{fed}$ ) was added before planting during soil preparation to stimulate germination and 


\section{Improvement of water use efficiency on potato production \\ 2- Calculated crop coefficient for potato crop under different irrigation regimes}

ammonium nitrate $(33.5 \% \mathrm{~N})$ was divided into two equal parts (at rate $200 \mathrm{~kg}$ ammonium nitrate in every part/fed) and applied at side dressing at 45 and 60 days after planting. While phosphorus $\left(62 \mathrm{~kg} \mathrm{P}_{2} \mathrm{O}_{5}\right)$ was applied before cultivation during soil preparation in a form of calcium super phosphate $\left(15.5 \% \mathrm{P}_{2} \mathrm{O}_{5}\right)$. Other cultural practices were done as a recommended for potato production. Soil analyses showed that soil texture was clay, field capacity $(38.2 \%)$ was determined by field method according to (Black 1965) and Kluke (1986). All the agronomic practice except the irrigation treatment and potassium rates were applied as a commonly use in growing.

\section{Soil - water relationships}

\section{Recorded data:}

\section{Water consumptive use (CU)}

The quantities of water consumptive use were calculated for the $60 \mathrm{~cm}$ soil depth which was assumed to be the depth of the roots zone as reported by many investigators.

Monthly and seasonal water consumptive use were calculated by the summation of water consumed for the different successive irrigation through the whole growth season. Water consumptive use per feddan $\left(4200 \mathrm{~m}^{2}\right)$ can be obtained by the following equation.

Where:

$$
\boldsymbol{C U}=\frac{\emptyset 2-\emptyset 1}{100} \times \boldsymbol{B} \cdot \boldsymbol{d} \times \frac{\text { Depth }}{100} \times \text { Area }\left(4200 \mathbf{m}^{2}\right)(\text { Israelsen and Hansen, 1962) }
$$

$\mathrm{CU}=$ Amount of water consumptive use.

$\theta_{2}=$ Soil moisture content $\%$ after irrigation.

$\theta_{1}=$ Soil moisture content befor the next irrigation.

b.d = Bulk density $\left(\mathrm{g} / \mathrm{cm}^{3}\right)$.

Calculation of $\mathrm{CU}$ was repeated for all irrigations until the harvesting date.

\section{Climatic Conditions}

Some meteorological data during the two growing seasons are present in Table (1). Metrological data obtained from metrological Mallawy Station located at the $27.9^{-}$latitude and $30.5^{-}$longitude and its altitude is about $44 \mathrm{~m}$ above sea level. These data are used to get potential evapotranspination $\mathrm{mm}$ /day by many empirical formula modified Penman, modified Blaney \& Criddle, radiation method and pan method.

Table (1): The average of temperature, relative humidity\%, wind speed (Km/day), sun shin (hours/day)and evaporation in the two studied seasons 2012\&2013.

\begin{tabular}{|c|c|c|c|c|c|c|c|c|c|c|}
\hline \multirow{2}{*}{ Month } & \multicolumn{3}{|c|}{ Temperature (C) } & \multicolumn{3}{|c|}{ Relative humidity (\%) } & \multirow{2}{*}{$\begin{array}{l}\text { Sunshine } \\
\text { (hours/\%) }\end{array}$} & \multicolumn{2}{|c|}{ Wind kg/day } & \multirow{2}{*}{$\begin{array}{l}\text { Evaporation } \\
\text { (mm/day) }\end{array}$} \\
\hline & Max. & Min. & Average & Max. & Min. & Average & & $M / s$ & Kg/day & \\
\hline September & 34.00 & 18.7 & 29.95 & 94.00 & 28.00 & 61.00 & 10.6 & 3.40 & 294.43 & 8.50 \\
\hline October & 33.00 & 16.6 & 24.80 & 92.00 & 27.00 & 59.50 & 9.90 & 2.90 & 251.13 & 6.71 \\
\hline November & 27.30 & 11.9 & 19.60 & 99.00 & 37.00 & 68.00 & 8.70 & 2.50 & 216.50 & 4.10 \\
\hline December & 21.05 & 6.70 & 13.87 & 99.58 & 43.29 & 71.44 & 8.42 & 2.35 & 203.51 & 2.66 \\
\hline
\end{tabular}


Abdel-Ati Y.Y. et al.

\section{Potential Evapotranspiration $\left(\mathbf{E T}_{\mathrm{P}}\right)$}

\section{1- Modified Pemman equation}

$$
E T_{P}=C\left\{\left(W \cdot R_{a}+1-W\right) \times F \cdot(u) \times\left(e_{a}-e_{d}\right)\right\}
$$

Where:

$\mathrm{ET}_{\mathrm{P}}=$ Reference crop evapotranspiration $\mathrm{mm} /$ day.

$\mathrm{W}=$ Temperature - related weighting factor.

$\mathrm{Rn}=$ Net radiation in equivalent evaporation in $\mathrm{mm} /$ day.

$\mathrm{F}(\mathrm{u})=$ Wind - related function.

ea $=$ Saturation vapour pressure of the air in (mbar).

ed $=$ Mean actual vapour pressure of the air in (mbar) $=$ ea $x$ RH mean/100, in which, $\mathrm{RH}=$ relative humidity.

(ea - ed $)=$ Difference between the saturation vapour pressure at mean air temperature and the mean atcual vapour pressure of the air, both in mbar.

$\mathrm{c}=$ Adjustment factor to compensate for the effect of day and night weather conditions.

\section{2- Modified Blaney \& Criddle equation}

Blaney and Criddle (1955) observed that the amount of water consumptive used by crop during the growing seasons was closely correlated with means monthly temperature and day light hours.

$$
E T_{P}=C\{P(0.64 T+8.13)\}
$$

Where:

$\mathrm{ET}_{\mathrm{p}}=$ Potential evapotranspiration in $\mathrm{mm} /$ day

$\mathrm{T}=$ Mean daily temperature in $\mathrm{C}^{\circ}$.

$\mathrm{P}=$ Mean daily percentage of total annual day time hours for given month and latitude.

$\mathrm{C}=$ Adjustment factor which depends on minimun relative humidity, sunshine hours and

day time wind estimate.

\section{3- Radiation method}

$$
E T_{P}=C \times W \cdot R_{s}
$$

Where:

$\mathrm{ET}_{\mathrm{P}}=$ Reference crop evapotranspiraion in $\mathrm{mm} /$ day.

Rs $=$ The solar radiation expressed in equivalent evaporation in $\mathrm{m} /$ day .

$\mathrm{W}=$ Weighting factor which depends on temperature and altitude.

$\mathrm{C}=$ Adjustment factor which depends on mean humidity and day time wind conditions.

\section{4- Pan evaporation method}

Reference crop evapotranspiration $\left(\mathrm{ET}_{\mathrm{P}}\right)$ can be obtained from the following equation

$$
E T_{P}=K_{P} \times E_{\text {pan }}
$$

Where:

$\mathrm{K}_{\mathrm{P}}=$ Pan coefficient depends on the type of Pan , condition of Humidity, wind speed and pan environmental conditions $(=0.75)$.

$\mathrm{E}_{\mathrm{pan}}=$ Pan evaporation in $\mathrm{mm} /$ day and represents the mean daily value of the period considered. 


\section{Improvement of water use efficiency on potato production \\ 2- Calculated crop coefficient for potato crop under different irrigation regimes}

\section{Crop Coefficient (Kc)}

Crop coefficient defined as the ratio between actual crop evapotranspiration (ETa) and potential evapotranspirtaion $\left(\mathrm{ET}_{\mathrm{P}}\right)$ when both are in large fields, under optimum growing conditions (FAO, 1977). In the experiment, the following equation was applied to compute the Kc values.

Where:

$$
K c=E T_{a} / E T_{p}
$$

$\mathrm{Kc}=$ Crop coefficient

$\mathrm{ET}_{\mathrm{a}}=$ Actual evapotranspirtation

$\mathrm{ET}_{\mathrm{p}}=$ potential evapotranspiration calculated by the four equations

( modified Penman, modified Blaney \& Criddle, radiation method, and pan evaporation method).

\section{Statistical analysis}

proper statistical analysis of all data was carried out according to program SPSS version 20 .

\section{RESULTS AND DISCUSSION \\ Seasonal actual water consumptive use: $\left(\mathrm{ET}_{\mathrm{a}}\right)$}

Seasonal water consumptive use ( $\mathrm{cm} / \mathrm{season})$ are present in Table (2). These results show that irrigation regime affect significantly in the two studied seasons. The highest value are $(43.76 \mathrm{~cm} / \mathrm{season})$ obtain from plants which irrigated by conventional irrigation (farmer practices) while, the lowest value are $(39.49 \mathrm{~cm} / \mathrm{season})$ obtain from plants which irrigated until $70 \%$ of field capacity this is due to a decrease in the amount of water applied which led to reducing the amount of water consumed for this treatment. Also results show potassium rates affect significantly in the two studied seasons where the mean values of seasonal water consumptive use are $40.84,41.37,40.33$ and $42.09 \mathrm{~cm} /$ season for $b_{1}, b_{2}, b_{3}$ and $b_{4}$, respectively. While the highest value are obtain from $b_{4}(42.09 \mathrm{~cm} / \mathrm{season})$ and the lowest value of obtain from $b_{1}$ and $b_{3}(40.84,40.33 \mathrm{~cm} /$ season), respectively. The reducing of seasonal ETa by increasing potassium rates can be attributed to these plants may retain with more water in their tissues to face the stress condition of the lack of water. The trudged cells of stomata that are rich in keep the stomata closed most of time, so transpiration rate decreased. However, there is no need for more water to absorb by plant roots which in turn reduce the amount of absorbed water. This result is logical as $\mathrm{K}$ well known to preserver more in plant tissues. Therefore, it is absorbed less water.

So these results reveal that the application of high levels of $\mathrm{K}$ fertilizer led to slight decreases in seasonal water consumptive use in the two studied seasons these results are in agreement with those reported by Abdel-Mottaleb (1987), Khalak and Kumaraswang (1996) and Gething (1997). With regard to the interactions between the studied factors, the results show that the highest value are obtain from $\mathrm{A}_{1} \mathrm{~b}_{4}(45.37 \mathrm{~cm} / \mathrm{season})$ during both seasons while the lowest value of actual water consumptive use obtion from plants which irrigated by $\mathrm{A}_{5}$ and $\mathrm{b}_{3}(38.18 \mathrm{~cm} / \mathrm{seasan})$. 
Abdel-Ati Y.Y. et al.

Table (2): Average values of seasonal water consumptive use $(\mathrm{cm} / \mathrm{seasons})$ for potato plants as affected irrigation regime and potassium fertilizer in both studied seasons.

\begin{tabular}{|c|c|c|c|c|c|}
\hline \multirow{3}{*}{$\begin{array}{l}\text { Treatments } \\
\text { Irrigation } \\
\text { regimes } \\
\text { (A) }\end{array}$} & \multicolumn{4}{|c|}{ water consumptive use (cm/season) } & \multirow{3}{*}{ Mean (A) } \\
\hline & \multicolumn{4}{|c|}{ Potassium fertilizer (B) } & \\
\hline & b1 & b2 & b3 & b4 & \\
\hline A1 & 42.96 & 44.04 & 42.67 & 45.37 & 43.76 \\
\hline A2 & 41.51 & 42.85 & 41.35 & 43.72 & 42.36 \\
\hline A3 & 40.67 & 41.45 & 40.38 & 42.36 & 41.22 \\
\hline A4 & 40.00 & 40.62 & 39.09 & 42.02 & 40.43 \\
\hline A5 & 39.05 & 39.70 & 38.18 & 41.03 & 39.49 \\
\hline Mean ( B ) & 40.84 & 41.37 & 40.33 & 42.09 & \\
\hline L.S.D. 5\% & $\mathrm{A}=\mathbf{1 . 4 6}$ & $\mathrm{B}=\mathbf{2 . 1 5}$ & \multicolumn{2}{|l|}{$\mathrm{AB}=4.80$} & \\
\hline \multicolumn{6}{|c|}{ 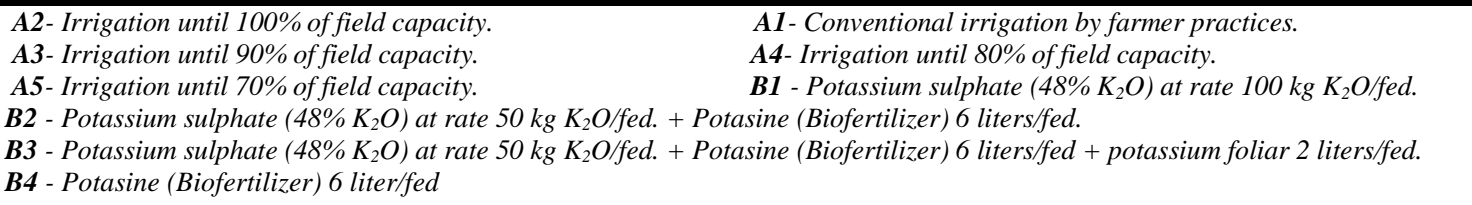 } \\
\hline
\end{tabular}

\section{Daily actual water consumptive use ( $\mathrm{mm} / \mathrm{day})$}

Daily data of actual consumptive use by the soil moisture depletion method, for potato crop is shown in Table (3). It could be notice that daily actual water consumptive use starts with small amount because small of little water needs of plants at initial growth stage, therefore, soil moisture are mainly affect by evaporation from soil surface at this time, with the advance with plant age, evapotranspiration increases and consequently the monthly consumptive use increased a plant foliage develops. The daily water consumptive use reaches its peak value in the middle of growing season (full formation of tubers), which is considered the critical period in water demands of crops. Then, it declines at the end of growing as the crop means the harvest and the water loss is almost due to evaporation from soil surface while a little is lost by consumptive use

\section{Potential evapotranspiration $\left(\right.$ ET $\left._{\mathbf{P}}\right)$}

Data in Table (4) show that the computed values daily, monthly and seasonal potential evapotranspiration ( $\mathrm{mm} / \mathrm{day}, \mathrm{mm} / \mathrm{month}$ and $\mathrm{mm} / \mathrm{season}$ ) according to modified Penman, modified Blaney \& Criddle, Radation method and Pan method for two studied seasons. It can be observe that the average lowest $\mathrm{ET}_{\mathrm{p}}(49.11 \mathrm{~mm} / \mathrm{season})$ values are obtain from pan method during the two studied seasons. While the average highest ET $_{\mathrm{p}}(63.24 \mathrm{~cm} / \mathrm{season})$ are obtain from modified Penman during the two studied seasons. It could be noticed from data in Table (5) that the nearest $\mathrm{ET}_{\mathrm{p}}$ values to the average are those which are obtain form Blaney and Criddle while, the fareast are those of modified Penman and Pan method. These results are in agreement with those of Doorenhboos and Pruitt (1975).

Table (3): Daily actual evapotranspiration $\left(\mathbf{E T}_{\mathrm{a}}\right)(\mathrm{mm} / \mathrm{day})$ for potato plants as affected by different treatments in the two studied seasons.

\begin{tabular}{|c|c|c|c|c|c|c|c|c|c|c|c|c|c|c|c|c|c|c|c|c|}
\hline \multirow{3}{*}{$\begin{array}{l}\text { Mon } \\
\text { th }\end{array}$} & \multicolumn{4}{|c|}{ A1 } & \multicolumn{4}{|c|}{ A2 } & \multicolumn{4}{|c|}{ A3 } & \multicolumn{4}{|c|}{ A4 } & \multicolumn{4}{|c|}{ A5 } \\
\hline & b1 & b2 & b3 & b4 & b1 & b2 & b3 & b4 & b1 & b2 & b3 & b4 & b1 & b2 & b3 & b4 & b1 & b2 & b3 & b4 \\
\hline & $\begin{array}{l}\mathrm{mm} \\
/ \text { day }\end{array}$ & $\begin{array}{l}\mathrm{mm} / \\
\text { day }\end{array}$ & $\begin{array}{l}\mathrm{mm} / \\
\text { day }\end{array}$ & $\begin{array}{l}\mathrm{mm} / \\
\text { day }\end{array}$ & $\begin{array}{l}\mathrm{mm} / \\
\text { day }\end{array}$ & $\begin{array}{c}\mathrm{mm} / \\
\text { day }\end{array}$ & $\begin{array}{c}\mathrm{mm} / \\
\text { day }\end{array}$ & $\begin{array}{l}\mathrm{mm} / \\
\text { day }\end{array}$ & $\begin{array}{c}\mathrm{mm} / \\
\text { day }\end{array}$ & $\begin{array}{c}\mathrm{mm} / \\
\text { day }\end{array}$ & $\begin{array}{c}\mathrm{mm} / \\
\text { day }\end{array}$ & $\begin{array}{c}\mathrm{mm} / \\
\text { day }\end{array}$ & $\begin{array}{c}\mathrm{mm} / \\
\text { day }\end{array}$ & $\begin{array}{c}\mathrm{mm} / \\
\text { day }\end{array}$ & $\begin{array}{c}\mathrm{mm} / \\
\text { day }\end{array}$ & $\begin{array}{l}\mathrm{mm} / \\
\text { day }\end{array}$ & $\begin{array}{c}\mathrm{mm} / \\
\text { day }\end{array}$ & $\begin{array}{l}\mathrm{mm} / \\
\text { day }\end{array}$ & $\begin{array}{l}\mathrm{mm} / \\
\text { day }\end{array}$ & $\begin{array}{l}\mathrm{mm} / \\
\text { day }\end{array}$ \\
\hline Sep. & 3.02 & 3.14 & 2.99 & 3.28 & 2.86 & 3.01 & 2.85 & 3.17 & 2.77 & 2.86 & 2.88 & 2.98 & 2.70 & 2.77 & 2.51 & 2.92 & 2.60 & 2.67 & 2.50 & 2.81 \\
\hline Oct. & 3.71 & 3.79 & 3.72 & 3.89 & 3.61 & 3.70 & 3.59 & 3.70 & 3.55 & 3.60 & 3.52 & 3.69 & 3.50 & 3.54 & 3.37 & 3.65 & 3.43 & 3.47 & 3.36 & 3.57 \\
\hline Nov. & 5.34 & 5.42 & 5.32 & 5.52 & 5.23 & 5.33 & 5.22 & 5.44 & 5.16 & 5.22 & 5.14 & 5.31 & 5.11 & 5.16 & 5.25 & 5.27 & 5.05 & 5.09 & 4.98 & 5.19 \\
\hline Dec. & 3.25 & 3.37 & 3.18 & 3.52 & 3.08 & 3.24 & 3.06 & 3.31 & 2.99 & 3.08 & 2.83 & 3.21 & 2.91 & 2.98 & 2.72 & 3.13 & 2.8 & 2.88 & 2.7 & 3.03 \\
\hline Ave. & 3.83 & 3.93 & 3.80 & 4.05 & 3.69 & 3.82 & 3.68 & 3.90 & 3.61 & 3.69 & 3.59 & 3.79 & 3.55 & 3.61 & 3.46 & 3.74 & 3.47 & 3.53 & 3.45 & 3.65 \\
\hline
\end{tabular}


Table (4): Computed daily monthly, seasonal evapotranspiration $(\mathrm{mm}) \mathrm{ET}_{\mathrm{p}}$ and deviation percentage in the two studies seasons.

\begin{tabular}{|c|c|c|c|c|c|c|c|c|c|c|c|}
\hline \multirow{2}{*}{$\begin{array}{l}\text { Empirical } \\
\text { formula }\end{array}$} & \multicolumn{2}{|c|}{ September } & \multicolumn{2}{|c|}{ October } & \multicolumn{2}{|c|}{ November } & \multicolumn{2}{|c|}{ December } & \multirow{2}{*}{\multicolumn{2}{|c|}{$\begin{array}{l}\text { Seasonal } \mathbf{E T}_{\mathrm{p}} \\
\mathrm{mm} / \mathrm{s} . \quad \mathrm{cm} / \mathrm{s}\end{array}$}} & \multirow{2}{*}{$\begin{array}{c}\text { Deviation } \\
\text { percentage }\end{array}$} \\
\hline & $\begin{array}{l}\text { Daily } \\
\text { (mm) }\end{array}$ & $\begin{array}{l}\text { Monthly } \\
(\mathbf{m m})\end{array}$ & $\begin{array}{l}\text { Daily } \\
(\mathbf{m m})\end{array}$ & $\begin{array}{l}\text { Monthly } \\
(\mathbf{m m})\end{array}$ & $\begin{array}{l}\text { Daily } \\
(\mathbf{m m})\end{array}$ & $\begin{array}{c}\text { Monthly } \\
(\mathbf{m m})\end{array}$ & $\begin{array}{l}\text { Daily } \\
(\mathbf{m m})\end{array}$ & $\begin{array}{l}\text { Monthly } \\
\text { (mm) }\end{array}$ & & & \\
\hline $\begin{array}{l}\text { Modified } \\
\text { Penman }\end{array}$ & 8.79 & 184.59 & 6.72 & 208.32 & 5.15 & 154.5 & 4.25 & 85 & 632.41 & 63.24 & +13.2 \\
\hline $\begin{array}{l}\text { Modified Blaney } \\
\text { \&Criddle }\end{array}$ & 6.78 & 142.38 & 6.01 & 186.31 & 4.97 & 149.1 & 4.39 & 87.8 & 565.59 & 56.56 & +1.24 \\
\hline $\begin{array}{l}\text { Radiation } \\
\text { methods }\end{array}$ & 7.13 & 149.73 & 5.86 & 181.66 & 4.57 & 137.1 & 3.85 & 77 & 545.49 & 54.55 & -2.36 \\
\hline Pan method & 4.49 & 94.29 & 5.23 & 162.13 & 4.99 & 149.7 & 4.25 & 85 & 491.12 & 49.11 & -12.09 \\
\hline Average & 6.7975 & 142.747 & 5.955 & 184.605 & 4.92 & 147.6 & 4.185 & 83.7 & 558.65 & & \\
\hline
\end{tabular}

\section{Crop coefficient $(\mathrm{Kc})$}

Effect of crop characteristics on crop water requirements are indicate by the crop coefficient $(\mathrm{Kc})$ which represents the relationship between reference potential $\left(\mathrm{ET}_{\mathrm{P}}\right)$ and actual crop evapotranspiration $\left(\mathrm{ET}_{\mathrm{a}}\right)$. Data of crop coefficient of potato crop every irrigation treatment calculated using the actual evapotranspiration $\left(\mathrm{ET}_{\mathrm{a}}\right)$ and potential evapotranspiration $\left(\mathrm{ET}_{\mathrm{p}}\right)$, where $\left(\mathrm{Kc}=\mathrm{ET}_{\mathrm{a}} / \mathrm{ET}_{\mathrm{p}}\right)$, using the modified Penman, modified Blaney and Criddle, Radiation method and Pan method. The values of Kc for irrigation treatments are shown in Tables (5-24) and Figure (1). It is clear that the values of Kc show a slight increase with time after planting till they reach their peak in Novmber (formation of tubers)and then they decrease again at the end of growth season. The highest $\mathrm{Kc}$ values are obtain from first irrigation treatment $\mathrm{A}_{1}(0.76)$ while the lowest $\mathrm{Kc}$ values obtained from fifth irrigation treatment $\mathrm{A}_{5}(0.68)$ under all semi - treatments, respictively. The values of crop coefficient average (Kc average) by many empirical formulae for irrigation treatment $\mathrm{A}_{1}$ were $0.74,0.76,0.74$ and 0.78 , with average equal $(0.76)$, for $\mathrm{A}_{2}$ were $0.70,0.71$, 0.71 and 0.76 with average equal $(0.72)$, for $A_{3}$ were $0.70,0.71,0.69$ and 0.74 with average equal (0.71), for $\mathrm{A}_{4}$ were $0.69,0.70,0.67$ and 0.72 with average equal $(0.70)$ and for $\mathrm{A}_{5}$ were $0.67,0.68,0.66$ and 0.71 with average equal $(0.68)$ under semi - treatments, respectively. It could be noticed that the nearest values to average Kc those modified Blaney \& Criddle while the farthest were those of pan method. These results are in agreement with those of Eid et al., (1987) and Stansell et al. (1990).

\section{The calculated evapotranspiration ( $\left.\mathbf{E T}_{\text {cal. }}\right)$}

The calculated evapotranspiration $\left(\mathrm{ET}_{\text {cal }}\right)$ ( $\left.\mathrm{cm} / \mathrm{season}\right)$ are shown in Table (25) for irrigation treatments using the relation $\mathrm{ET}_{\text {cal }}=\mathrm{Kc}$ average $\mathrm{X} \mathrm{ET}_{\mathrm{p}}$ and its comparison with actual consumptive use $\left(\mathrm{ET}_{\mathrm{a}}\right.$ ) for different irrigation treatments. Data in Table (25) and Figure (2) indicate that calculated evapotranspiration $\left(\mathrm{ET}_{\mathrm{cal}}\right)$ by radiation method and modified Blaney \& Criddle method were easily clarify the degree of the calculated evapotranspiration where it nearest to actual water consumptive use than other equations. So, it could be recommended to use the equation radiation method followed by modified Blaney \& Criddle for estimating $\mathrm{ET}_{\mathrm{p}}$ in Minia region with the average crop coefficient due to the highest accruing for potato. These results are in agreement with those reported by Semika, and Rady (1987) and EI-Tantawy (1997). 
Abdel-Ati Y.Y.et al.

Table (5): The crop coefficient $\left(K c=E T_{a} / E T_{p}\right)$ for treatment $\left(A_{1} b_{1}\right)$ for potato crop in two studied seasons.

\begin{tabular}{|c|c|c|c|c|c|c|c|c|c|c|}
\hline & \multirow{3}{*}{$\begin{array}{c}\text { Average }(\mathbf{C U}) \text { in } \\
\text { two seasons } \\
\mathrm{mm} / \mathrm{day}\end{array}$} & \multicolumn{9}{|c|}{ Average potential evapotranspiration $(\mathrm{mm} / \mathrm{day})$ to both } \\
\hline & & \multicolumn{2}{|c|}{$\begin{array}{c}\text { Modified } \\
\text { penman }\end{array}$} & \multicolumn{2}{|c|}{$\begin{array}{c}\text { Modified } \\
\text { Blaney \& } \\
\text { Criddle }\end{array}$} & \multicolumn{2}{|c|}{$\begin{array}{c}\text { Radiation } \\
\text { method }\end{array}$} & \multicolumn{2}{|c|}{ Pan method } & \multirow[t]{2}{*}{$\begin{array}{c}\text { Average } \\
\text { (kc) }\end{array}$} \\
\hline & & mm/day & KC & mm/day & KC & mm/day & KC & mm/day & KC & \\
\hline Sept & 3.02 & 8.79 & 0.34 & 6.78 & 0.45 & 7.13 & 0.42 & 4.49 & 0.67 & 0.47 \\
\hline Oct. & 3.71 & 6.72 & 0.55 & 6.01 & 0.62 & 5.86 & 0.63 & 5.23 & 0.71 & 0.63 \\
\hline Nov. & 5.34 & 5.15 & 1.04 & 4.97 & 1.07 & 4.57 & 1.17 & 4.99 & 1.07 & 1.09 \\
\hline Dec. & 3.25 & 4.25 & 0.76 & 4.36 & 0.75 & 3.85 & 0.84 & 4.25 & 0.76 & 0.78 \\
\hline Average & 3.83 & 6.23 & 0.67 & 5.53 & 0.72 & 5.35 & 0.77 & 4.74 & 0.80 & 0.74 \\
\hline \multirow[t]{2}{*}{$\begin{array}{c}\text { Index } \\
\text { Number }\end{array}$} & & & 90.54 & & 97.30 & & 104.05 & & 108.11 & 100.00 \\
\hline & & & 4 & & 1 & & 2 & & 3 & \\
\hline
\end{tabular}

- (CU): Actual consumptive use

Table (6): The crop coefficient $\left(\mathrm{Kc}=\mathrm{ET} \mathrm{a}_{\mathrm{a}} / \mathrm{ET} \mathrm{p}_{\mathrm{p}}\right)$ for treatment $\left(\mathrm{A}_{1} \mathrm{~b}_{2}\right)$ for potato crop in two studied seasons.

\begin{tabular}{|c|c|c|c|c|c|c|c|c|c|c|}
\hline & \multirow{3}{*}{$\begin{array}{c}\text { Average }(\mathbf{C U}) \text { in } \\
\text { two seasons } \\
\mathrm{mm} / \mathrm{day}\end{array}$} & \multicolumn{9}{|c|}{ Average potential evapotranspiration $(\mathrm{mm} / \mathrm{day})$ to both } \\
\hline & & \multicolumn{2}{|c|}{$\begin{array}{c}\text { Modified } \\
\text { penman }\end{array}$} & \multicolumn{2}{|c|}{$\begin{array}{c}\text { Modified } \\
\text { Blaney \& } \\
\text { Criddle }\end{array}$} & \multicolumn{2}{|c|}{$\begin{array}{l}\text { Radiation } \\
\text { method }\end{array}$} & \multicolumn{2}{|c|}{ Pan method } & \multirow[t]{2}{*}{$\begin{array}{c}\text { Average } \\
\text { (kc) }\end{array}$} \\
\hline & & $\mathrm{mm} / \mathrm{day}$ & KC & mm/day & $\mathbf{K C}$ & mm/day & KC & mm/day & KC & \\
\hline Sept & 3.14 & 8.79 & 0.36 & 6.78 & 0.46 & 7.13 & 0.44 & 4.49 & 0.70 & 0.49 \\
\hline Oct. & 3.79 & 6.72 & 0.56 & 6.01 & 0.63 & 5.86 & 0.65 & 5.23 & 0.72 & 0.64 \\
\hline Nov. & 5.42 & 5.15 & 1.05 & 4.97 & 1.09 & 4.57 & 1.19 & 4.99 & 1.09 & 1.10 \\
\hline Dec. & 3.37 & 4.25 & 0.79 & 4.36 & 0.77 & 3.85 & 0.88 & 4.25 & 0.79 & 0.81 \\
\hline Average & 3.93 & 6.23 & 0.69 & 5.53 & 0.74 & 5.35 & 0.79 & 4.74 & 0.83 & 0.76 \\
\hline \multirow[t]{2}{*}{$\begin{array}{c}\text { Index } \\
\text { Number }\end{array}$} & & & 90.79 & & 97.37 & & 103.95 & & 109.21 & 100.00 \\
\hline & & & 4 & & 1 & & 2 & & 3 & \\
\hline
\end{tabular}

- (CU): Actual consumptive use

Table (7): The crop coefficient $\left(K c=E T_{a} / E T_{p}\right)$ for treatment $\left(A_{1} b_{3}\right)$ for potato crop in two studied seasons.

\begin{tabular}{|c|c|c|c|c|c|c|c|c|c|c|}
\hline & \multirow{3}{*}{$\begin{array}{c}\text { Average }(\mathrm{CU}) \text { in } \\
\text { two seasons } \\
\text { mm/day }\end{array}$} & \multicolumn{9}{|c|}{ Average potential evapotranspiration $(\mathrm{mm} /$ day) to both } \\
\hline & & \multicolumn{2}{|c|}{$\begin{array}{l}\text { Modified } \\
\text { penman }\end{array}$} & \multicolumn{2}{|c|}{$\begin{array}{c}\text { Modified } \\
\text { Blaney \& } \\
\text { Criddle }\end{array}$} & \multicolumn{2}{|c|}{$\begin{array}{l}\text { Radiation } \\
\text { method }\end{array}$} & \multicolumn{2}{|c|}{ Pan method } & \multirow[t]{2}{*}{$\begin{array}{c}\text { Average } \\
\text { (kc) }\end{array}$} \\
\hline & & mm/day & KC & mm/day & KC & mm/day & KC & $\mathbf{m m} /$ day & KC & \\
\hline Sept & 2.99 & 8.79 & 0.34 & 6.78 & 0.44 & 7.13 & 0.42 & 4.49 & 0.67 & 0.47 \\
\hline Oct. & 3.72 & 6.72 & 0.55 & 6.01 & 0.62 & 5.86 & 0.63 & 5.23 & 0.71 & 0.63 \\
\hline Nov. & 5.32 & 5.15 & 1.03 & 4.97 & 1.07 & 4.57 & 1.16 & 4.99 & 1.07 & 1.08 \\
\hline Dec. & 3.18 & 4.25 & 0.75 & 4.36 & 0.73 & 3.85 & 0.83 & 4.25 & 0.75 & 0.76 \\
\hline Average & 3.80 & 6.23 & 0.67 & 5.53 & 0.71 & 5.35 & 0.76 & 4.74 & 0.80 & 0.74 \\
\hline \multirow[t]{2}{*}{$\begin{array}{c}\text { Index } \\
\text { Number }\end{array}$} & & & 90.54 & & 95.95 & & 102.70 & & 108.11 & 100.00 \\
\hline & & & 4 & & 1 & & 2 & & 3 & \\
\hline
\end{tabular}


Improvement of water use efficiency on potato production

2- Calculated crop coefficient for potato crop under different irrigation regimes

Table (8): The crop coefficient $\left(K c=E T_{a} / E T_{p}\right)$ for treatment $\left(A_{1} b_{4}\right)$ for potato crop in two studied seasons.

\begin{tabular}{|c|c|c|c|c|c|c|c|c|c|c|}
\hline & \multirow{3}{*}{$\begin{array}{c}\text { Average }(\mathrm{CU}) \text { in } \\
\text { two seasons } \\
\mathrm{mm} / \text { day }\end{array}$} & \multicolumn{9}{|c|}{ Average potential evapotranspiration $(\mathrm{mm} /$ day) to both } \\
\hline & & \multicolumn{2}{|c|}{$\begin{array}{c}\text { Modified } \\
\text { penman }\end{array}$} & \multicolumn{2}{|c|}{$\begin{array}{c}\text { Modified } \\
\text { Blaney \& } \\
\text { Criddle }\end{array}$} & \multicolumn{2}{|c|}{$\begin{array}{c}\text { Radiation } \\
\text { method }\end{array}$} & \multicolumn{2}{|c|}{ Pan method } & \multirow[t]{2}{*}{$\begin{array}{c}\text { Average } \\
\text { (kc) }\end{array}$} \\
\hline & & mm/day & KC & $\mathrm{mm} / \mathrm{day}$ & KC & $\mathbf{m m} /$ day & KC & $\mathbf{m m} /$ day & KC & \\
\hline Sept & 3.28 & 8.79 & 0.37 & 6.78 & 0.48 & 7.13 & 0.46 & 4.49 & 0.73 & 0.51 \\
\hline Oct. & 3.89 & 6.72 & 0.58 & 6.01 & 0.65 & 5.86 & 0.66 & 5.23 & 0.74 & 0.66 \\
\hline Nov. & 5.52 & 5.15 & 1.07 & 4.97 & 1.11 & 4.57 & 1.21 & 4.99 & 1.11 & 1.12 \\
\hline Dec. & 3.52 & 4.25 & 0.83 & 4.36 & 0.81 & 3.85 & 0.91 & 4.25 & 0.83 & 0.84 \\
\hline Average & 4.05 & 6.23 & 0.71 & 5.53 & 0.76 & 5.35 & 0.81 & 4.74 & 0.85 & 0.78 \\
\hline \multirow[t]{2}{*}{$\begin{array}{c}\text { Index } \\
\text { Number }\end{array}$} & & & 91.03 & & 97.44 & & 103.84 & & 108.97 & 100.00 \\
\hline & & & 4 & & 1 & & 2 & & 3 & \\
\hline
\end{tabular}

- $\quad(C U):$ Actual consumptive use

Table (9): The crop coefficient $\left(K c=E T_{a} / E T_{p}\right)$ for treatment $\left(A_{2} b_{1}\right)$ for potato crop in two studied seasons.

\begin{tabular}{|c|c|c|c|c|c|c|c|c|c|c|}
\hline & \multirow{3}{*}{$\begin{array}{c}\text { Average }(\mathrm{CU}) \text { in } \\
\text { two seasons } \\
\text { mm/day }\end{array}$} & \multicolumn{9}{|c|}{ Average potential evapotranspiration $(\mathrm{mm} /$ day) to both } \\
\hline & & \multicolumn{2}{|c|}{$\begin{array}{c}\text { Modified } \\
\text { penman }\end{array}$} & \multicolumn{2}{|c|}{$\begin{array}{c}\text { Modified } \\
\text { Blaney \& } \\
\text { Criddle }\end{array}$} & \multicolumn{2}{|c|}{$\begin{array}{c}\text { Radiation } \\
\text { method }\end{array}$} & \multicolumn{2}{|c|}{ Pan method } & \multirow[t]{2}{*}{$\begin{array}{c}\text { Average } \\
\text { (kc) }\end{array}$} \\
\hline & & $\mathbf{m m} /$ day & KC & mm/day & KC & $\mathbf{m m} / \mathbf{d a y}$ & KC & mm/day & KC & \\
\hline $\begin{array}{c}\text { Sept } \\
\text { Oct. } \\
\text { Nov. } \\
\text { Dec. } \\
\text { Average }\end{array}$ & $\begin{array}{l}2.77 \\
3.55 \\
5.16 \\
2.99 \\
\mathbf{3 . 6 2} \\
\end{array}$ & $\begin{array}{l}8.79 \\
6.72 \\
5.15 \\
4.25 \\
\mathbf{6 . 2 3}\end{array}$ & $\begin{array}{l}0.32 \\
0.53 \\
1.00 \\
0.70 \\
\mathbf{0 . 6 4}\end{array}$ & $\begin{array}{l}6.78 \\
6.01 \\
4.97 \\
4.36 \\
\mathbf{5 . 5 3}\end{array}$ & $\begin{array}{l}0.41 \\
0.59 \\
1.04 \\
0.69 \\
\mathbf{0 . 6 8}\end{array}$ & $\begin{array}{l}7.13 \\
5.86 \\
4.57 \\
3.85 \\
\mathbf{5 . 3 5}\end{array}$ & $\begin{array}{l}0.39 \\
0.61 \\
1.13 \\
0.78 \\
\mathbf{0 . 7 3}\end{array}$ & $\begin{array}{l}4.49 \\
5.23 \\
4.99 \\
4.25 \\
\mathbf{4 . 7 4}\end{array}$ & $\begin{array}{l}0.62 \\
0.68 \\
1.03 \\
0.70 \\
\mathbf{0 . 7 6}\end{array}$ & $\begin{array}{l}0.43 \\
0.60 \\
1.05 \\
0.72 \\
\mathbf{0 . 7 0} \\
\end{array}$ \\
\hline $\begin{array}{c}\text { Index } \\
\text { Number }\end{array}$ & & & $\begin{array}{c}91.43 \\
4\end{array}$ & & $\begin{array}{c}97.14 \\
1\end{array}$ & & $\begin{array}{c}104.20 \\
2\end{array}$ & & $\begin{array}{c}108.57 \\
3\end{array}$ & 100.00 \\
\hline
\end{tabular}

- (CU): Actual consumptive use

Table (10): The crop coefficient $\left(\mathrm{Kc}=\mathrm{ET} \mathrm{a}_{\mathrm{a}} / \mathrm{ET} \mathrm{T}_{\mathrm{p}}\right)$ for treatment $\left(\mathrm{A}_{2} \mathrm{~b}_{2}\right)$ for potato crop in two studied seasons.

\begin{tabular}{|c|c|c|c|c|c|c|c|c|c|c|}
\hline & \multirow{3}{*}{$\begin{array}{c}\begin{array}{c}\text { Average }(\mathrm{CU}) \text { in } \\
\text { two seasons }\end{array} \\
\mathrm{mm} / \mathrm{day}\end{array}$} & \multicolumn{9}{|c|}{ Average potential evapotranspiration $(\mathrm{mm} / \mathrm{day})$ to both } \\
\hline & & \multicolumn{2}{|c|}{$\begin{array}{c}\text { Modified } \\
\text { penman }\end{array}$} & \multicolumn{2}{|c|}{$\begin{array}{c}\text { Modified } \\
\text { Blaney \& } \\
\text { Criddle }\end{array}$} & \multicolumn{2}{|c|}{$\begin{array}{c}\text { Radiation } \\
\text { method }\end{array}$} & \multicolumn{2}{|c|}{ Pan method } & \multirow[t]{2}{*}{$\begin{array}{c}\text { Average } \\
\text { (kc) }\end{array}$} \\
\hline & & mm/day & $\mathrm{KC}$ & mm/day & KC & mm/day & KC & mm/day & KC & \\
\hline Sept & 2.86 & 8.79 & 0.33 & 6.78 & 0.42 & 7.13 & 0.40 & 4.49 & 0.64 & 0.45 \\
\hline Oct. & 3.60 & 6.72 & 0.54 & 6.01 & 0.60 & 5.86 & 0.61 & 5.23 & 0.69 & 0.61 \\
\hline Nov. & 5.22 & 5.15 & 1.01 & 4.97 & 1.05 & 4.57 & 1.14 & 4.99 & 1.05 & 1.06 \\
\hline Dec. & 3.08 & 4.25 & 0.72 & 4.36 & 0.71 & 3.85 & 0.80 & 4.25 & 0.72 & 0.74 \\
\hline Average & 3.69 & 6.23 & 0.65 & 5.53 & 0.69 & 5.35 & 0.74 & 4.74 & 0.77 & 0.71 \\
\hline \multirow[t]{2}{*}{$\begin{array}{c}\text { Index } \\
\text { Number }\end{array}$} & & & 91.55 & & 97.18 & & 104.22 & & 108.45 & 100.00 \\
\hline & & & 4 & & 1 & & 2 & & 3 & \\
\hline
\end{tabular}

- $\quad(C U):$ Actual consumptive use 
Abdel-Ati Y.Y. et al.

Table (11): The crop coefficient $\left(\mathrm{Kc}=\mathrm{ET} \mathrm{a}_{\mathrm{a}} / \mathrm{ET} \mathrm{p}_{\mathrm{p}}\right)$ for treatment $\left(\mathrm{A}_{2} \mathrm{~b}_{3}\right)$ for potato crop in two studied seasons.

\begin{tabular}{|c|c|c|c|c|c|c|c|c|c|c|}
\hline & \multirow{3}{*}{$\begin{array}{c}\text { Average }(\mathbf{C U}) \text { in } \\
\text { two seasons } \\
\mathrm{mm} / \mathrm{day}\end{array}$} & \multicolumn{9}{|c|}{ Average potential evapotranspiration $(\mathrm{mm} / \mathrm{day})$ to both } \\
\hline & & \multicolumn{2}{|c|}{$\begin{array}{l}\text { Modified } \\
\text { penman }\end{array}$} & \multicolumn{2}{|c|}{$\begin{array}{c}\text { Modified } \\
\text { Blaney \& } \\
\text { Criddle }\end{array}$} & \multicolumn{2}{|c|}{$\begin{array}{c}\text { Radiation } \\
\text { method }\end{array}$} & \multicolumn{2}{|c|}{ Pan method } & \multirow[t]{2}{*}{$\begin{array}{c}\text { Average } \\
\text { (kc) }\end{array}$} \\
\hline & & mm/day & KC & mm/day & KC & mm/day & KC & mm/day & KC & \\
\hline Sept & 2.85 & 8.79 & 0.32 & 6.78 & 0.42 & 7.13 & 0.40 & 4.49 & 0.63 & 0.44 \\
\hline Oct. & 3.59 & 6.72 & 0.53 & 6.01 & 0.60 & 5.86 & 0.61 & 5.23 & 0.69 & 0.61 \\
\hline Nov. & 5.22 & 5.15 & 1.01 & 4.97 & 1.05 & 4.57 & 1.14 & 4.99 & 1.05 & 1.06 \\
\hline Dec. & 3.06 & 4.25 & 0.72 & 4.36 & 0.70 & 3.85 & 0.79 & 4.25 & 0.72 & 0.73 \\
\hline Average & 3.68 & 6.23 & 0.65 & 5.53 & 0.69 & 5.35 & 0.74 & 4.74 & 0.77 & 0.71 \\
\hline \multirow[t]{2}{*}{$\begin{array}{c}\text { Index } \\
\text { Number }\end{array}$} & & & 91.55 & & 97.18 & & 104.23 & & 108.45 & 100.00 \\
\hline & & & 4 & & 1 & & 2 & & 3 & \\
\hline
\end{tabular}

- (CU): Actual consumptive use

Table (12): The crop coefficient $\left(\mathrm{Kc}=\mathrm{ET} \mathrm{a}_{\mathrm{a}} / \mathrm{ET} \mathrm{T}_{\mathrm{p}}\right)$ for treatment $\left(\mathrm{A}_{2} \mathrm{~b}_{4}\right)$ for potato crop in two studied seasons.

\begin{tabular}{|c|c|c|c|c|c|c|c|c|c|c|}
\hline & \multirow{3}{*}{$\begin{array}{c}\begin{array}{c}\text { Average }(\mathrm{CU}) \text { in } \\
\text { two seasons }\end{array} \\
\mathrm{mm} / \mathrm{day}\end{array}$} & \multicolumn{9}{|c|}{ Average potential evapotranspiration $(\mathrm{mm} / \mathrm{day})$ to both } \\
\hline & & \multicolumn{2}{|c|}{$\begin{array}{c}\text { Modified } \\
\text { penman }\end{array}$} & \multicolumn{2}{|c|}{$\begin{array}{c}\text { Modified } \\
\text { Blaney \& } \\
\text { Criddle }\end{array}$} & \multicolumn{2}{|c|}{$\begin{array}{c}\text { Radiation } \\
\text { method }\end{array}$} & \multicolumn{2}{|c|}{ Pan method } & \multirow[t]{2}{*}{$\begin{array}{c}\text { Average } \\
\text { (kc) }\end{array}$} \\
\hline & & mm/day & $\mathrm{KC}$ & mm/day & $\mathrm{KC}$ & $\mathrm{mm} / \mathrm{day}$ & KC & mm/day & KC & \\
\hline Sept & 3.17 & 8.79 & 0.36 & 6.78 & 0.47 & 7.13 & 0.44 & 4.49 & 0.71 & 0.49 \\
\hline Oct. & 3.7 & 6.72 & 0.55 & 6.01 & 0.62 & 5.86 & 0.63 & 5.23 & 0.71 & 0.63 \\
\hline Nov. & 5.44 & 5.15 & 1.06 & 4.97 & 1.09 & 4.57 & 1.19 & 4.99 & 1.09 & 1.11 \\
\hline Dec. & 3.31 & 4.25 & 0.78 & 4.36 & 0.76 & 3.85 & 0.86 & 4.25 & 0.78 & 0.79 \\
\hline Average & 3.91 & 6.23 & 0.69 & 5.53 & 0.73 & 5.35 & 0.78 & 4.74 & 0.82 & 0.76 \\
\hline \multirow[t]{2}{*}{$\begin{array}{c}\text { Index } \\
\text { Number }\end{array}$} & & & 90.79 & & 96.5 & & 102.63 & & 107.89 & 100.00 \\
\hline & & & 4 & & 1 & & 2 & & 3 & \\
\hline
\end{tabular}

- $\quad(C U)$ : Actual consumptive use

Table (13): The crop coefficient $\left(K c=E T_{a} / E T_{p}\right)$ for treatment $\left(A_{3} b_{1}\right)$ for potato crop in two studied seasons.

\begin{tabular}{|c|c|c|c|c|c|c|c|c|c|c|}
\hline & \multirow{3}{*}{$\begin{array}{c}\text { Average }(\mathrm{CU}) \text { in } \\
\text { two seasons } \\
\text { mm/day }\end{array}$} & \multicolumn{9}{|c|}{ Average potential evapotranspiration $(\mathrm{mm} / \mathrm{day})$ to both } \\
\hline & & \multicolumn{2}{|c|}{$\begin{array}{c}\text { Modified } \\
\text { penman }\end{array}$} & \multicolumn{2}{|c|}{$\begin{array}{c}\text { Modified } \\
\text { Blaney \& } \\
\text { Criddle }\end{array}$} & \multicolumn{2}{|c|}{$\begin{array}{c}\text { Radiation } \\
\text { method }\end{array}$} & \multicolumn{2}{|c|}{ Pan method } & \multirow[t]{2}{*}{$\begin{array}{c}\text { Average } \\
\text { (kc) }\end{array}$} \\
\hline & & mm/day & KC & $\mathbf{m m} / \mathbf{d a y}$ & KC & $\mathbf{m m} / \mathbf{d a y}$ & KC & $\mathbf{m m} / \mathbf{d a y}$ & KC & \\
\hline Sept & 2.77 & 8.79 & 0.32 & 6.78 & 0.41 & 7.13 & 0.39 & 4.49 & 0.62 & 0.43 \\
\hline Oct. & 3.55 & 6.72 & 0.53 & 6.01 & 0.59 & 5.86 & 0.61 & 5.23 & 0.68 & 0.60 \\
\hline Nov. & 5.16 & 5.15 & 1.00 & 4.97 & 1.04 & 4.57 & 1.13 & 4.99 & 1.03 & 1.05 \\
\hline Dec. & 2.99 & 4.25 & 0.70 & 4.36 & 0.69 & 3.85 & 0.78 & 4.25 & 0.70 & 0.72 \\
\hline Average & 3.62 & 6.23 & 0.64 & 5.53 & 0.68 & 5.35 & 0.73 & 4.74 & 0.76 & 0.70 \\
\hline \multirow[t]{2}{*}{$\begin{array}{c}\text { Index } \\
\text { Number }\end{array}$} & & & 91.43 & & 97.14 & & 104.29 & & 108.57 & 100.00 \\
\hline & & & 4 & & 1 & & 2 & & 3 & \\
\hline
\end{tabular}

- $\quad(C U):$ Actual consumptive use 
Table (14): The crop coefficient $\left(\mathrm{Kc}=\mathrm{ET} \mathrm{a}_{\mathrm{a}} / \mathrm{ET} \mathrm{T}_{\mathrm{p}}\right)$ for treatment $\left(\mathrm{A}_{3} \mathrm{~b}_{2}\right)$ for potato crop in two studied seasons.

\begin{tabular}{|c|c|c|c|c|c|c|c|c|c|c|}
\hline & \multirow{3}{*}{$\begin{array}{c}\text { Average (CU) } \\
\text { in two seasons } \\
\text { mm/day }\end{array}$} & \multicolumn{9}{|c|}{ Average potential evapotranspiration $(\mathrm{mm} /$ day) to both } \\
\hline & & \multicolumn{2}{|c|}{$\begin{array}{c}\text { Modified } \\
\text { penman }\end{array}$} & \multicolumn{2}{|c|}{$\begin{array}{c}\text { Modified } \\
\text { Blaney \& } \\
\text { Criddle }\end{array}$} & \multicolumn{2}{|c|}{$\begin{array}{l}\text { Radiation } \\
\text { method }\end{array}$} & \multicolumn{2}{|c|}{ Pan method } & \multirow[t]{2}{*}{$\begin{array}{c}\text { Average } \\
\text { (kc) }\end{array}$} \\
\hline & & mm/day & KC & $\mathbf{m m} / \mathbf{d a y}$ & KC & $\mathbf{m m} / \mathbf{d a y}$ & KC & mm/day & $\mathbf{K C}$ & \\
\hline Sept. & 2.86 & 8.79 & 0.33 & 6.78 & 0.42 & 7.13 & 0.40 & 4.49 & 0.64 & 0.45 \\
\hline Oct. & 3.6 & 6.72 & 0.54 & 6.01 & 0.60 & 5.86 & 0.61 & 5.23 & 0.69 & 0.61 \\
\hline Nov. & 5.22 & 5.15 & 1.01 & 4.97 & 1.05 & 4.57 & 1.14 & 4.99 & 1.05 & 1.06 \\
\hline Dec. & 3.08 & 4.25 & 0.72 & 4.36 & 0.71 & 3.85 & 0.80 & 4.25 & 0.72 & 0.74 \\
\hline Average & 3.69 & 6.23 & 0.65 & 5.53 & 0.69 & 5.35 & 0.74 & 4.74 & 0.77 & 0.71 \\
\hline \multirow[t]{2}{*}{$\begin{array}{c}\text { Index } \\
\text { Number }\end{array}$} & & & 91.55 & & 97.18 & & 104.23 & & 108.45 & 100.00 \\
\hline & & & 4 & & 1 & & 2 & & 3 & \\
\hline
\end{tabular}

- $\quad(C U)$ : Actual consumptive use

Table (15): The crop coefficient $\left(\mathrm{Kc}=\mathrm{ET} \mathrm{a}_{\mathrm{a}} / \mathrm{ET} \mathrm{T}_{\mathrm{p}}\right)$ for treatment $\left(\mathrm{A}_{3} \mathrm{~b}_{3}\right)$ for potato crop in two studied seasons.

\begin{tabular}{|c|c|c|c|c|c|c|c|c|c|c|}
\hline & \multirow{3}{*}{$\begin{array}{c}\text { Average (CU) } \\
\text { in two seasons } \\
\text { mm/day }\end{array}$} & \multicolumn{9}{|c|}{ Average potential evapotranspiration $(\mathrm{mm} / \mathrm{day})$ to both } \\
\hline & & \multicolumn{2}{|c|}{$\begin{array}{l}\text { Modified } \\
\text { penman }\end{array}$} & \multicolumn{2}{|c|}{$\begin{array}{c}\text { Modified } \\
\text { Blaney \& } \\
\text { Criddle } \\
\end{array}$} & \multicolumn{2}{|c|}{$\begin{array}{l}\text { Radiation } \\
\text { method }\end{array}$} & \multicolumn{2}{|c|}{ Pan method } & \multirow[t]{2}{*}{$\begin{array}{c}\text { Average } \\
\text { (kc) }\end{array}$} \\
\hline & & mm/day & KC & mm/day & KC & mm/day & KC & mm/day & KC & \\
\hline Sept. & 2.86 & 8.79 & 0.33 & 6.78 & 0.42 & 7.13 & 0.40 & 4.49 & 0.64 & 0.45 \\
\hline Oct. & 3.6 & 6.72 & 0.54 & 6.01 & 0.60 & 5.86 & 0.61 & 5.23 & 0.69 & 0.61 \\
\hline Nov. & 5.22 & 5.15 & 1.01 & 4.97 & 1.05 & 4.57 & 1.14 & 4.99 & 1.05 & 1.06 \\
\hline Dec. & 3.08 & 4.25 & 0.72 & 4.36 & 0.71 & 3.85 & 0.80 & 4.25 & 0.72 & 0.74 \\
\hline Average & 3.69 & 6.23 & 0.65 & 5.53 & 0.69 & 5.35 & 0.74 & 4.74 & 0.77 & 0.71 \\
\hline \multirow[t]{2}{*}{$\begin{array}{c}\text { Index } \\
\text { Number }\end{array}$} & & & 91.55 & & 97.18 & & 104.23 & & 108.45 & 100.00 \\
\hline & & & 4 & & 1 & & 2 & & 3 & \\
\hline
\end{tabular}

- (CU): Actual consumptive use

Table (16): The crop coefficient $\left(\mathrm{Kc}=\mathrm{ET} / \mathrm{ET} \mathrm{T}_{\mathrm{p}}\right)$ for treatment $\left(\mathrm{A}_{3} \mathrm{~b}_{4}\right)$ for potato crop in two studied seasons.

\begin{tabular}{|c|c|c|c|c|c|c|c|c|c|c|}
\hline & \multirow{3}{*}{$\begin{array}{c}\begin{array}{c}\text { Average }(C U) \text { in } \\
\text { two seasons }\end{array} \\
\text { mm/day }\end{array}$} & \multicolumn{9}{|c|}{ Average potential evapotranspiration (mm/day) to both } \\
\hline & & \multicolumn{2}{|c|}{$\begin{array}{l}\text { Modified } \\
\text { penman }\end{array}$} & \multicolumn{2}{|c|}{$\begin{array}{c}\text { Modified } \\
\text { Blaney \& } \\
\text { Criddle } \\
\end{array}$} & \multicolumn{2}{|c|}{$\begin{array}{l}\text { Radiation } \\
\text { method }\end{array}$} & \multicolumn{2}{|c|}{ Pan method } & \multirow[t]{2}{*}{$\begin{array}{c}\text { Average } \\
\text { (kc) }\end{array}$} \\
\hline & & mm/day & $\mathbf{K C}$ & $\mathbf{m m} / \mathbf{d a y}$ & KC & $\mathbf{m m} / \mathbf{d a y}$ & KC & mm/day & KC & \\
\hline Sept. & 2.98 & 8.79 & 0.34 & 6.78 & 0.44 & 7.13 & 0.42 & 4.49 & 0.66 & 0.47 \\
\hline Oct. & 3.69 & 6.72 & 0.55 & 6.01 & 0.61 & 5.86 & 0.63 & 5.23 & 0.71 & 0.62 \\
\hline Nov. & 5.31 & 5.15 & 1.03 & 4.97 & 1.07 & 4.57 & 1.16 & 4.99 & 1.06 & 1.08 \\
\hline Dec. & 3.21 & 4.25 & 0.76 & 4.36 & 0.74 & 3.85 & 0.83 & 4.25 & 0.76 & 0.77 \\
\hline Average & 3.80 & 6.23 & 0.67 & 5.53 & 0.71 & 5.35 & 0.76 & 4.74 & 0.80 & 0.74 \\
\hline \multirow[t]{2}{*}{$\begin{array}{l}\text { Index } \\
\text { Number }\end{array}$} & & & 90.54 & & 0.96 & & 102.70 & & 108.11 & 100.00 \\
\hline & & & 4 & & 1 & & 2 & & 3 & \\
\hline
\end{tabular}

\footnotetext{
- $\quad(C U):$ Actual consumptive use
} 
Abdel-Ati Y.Y.et al.

Table (17): The crop coefficient $\left(\mathrm{Kc}=\mathrm{ET}_{\mathrm{a}} / \mathrm{ET}_{\mathrm{p}}\right)$ for treatment $\left(\mathrm{A}_{4} \mathrm{~b}_{1}\right)$ for potato crop in two studied seasons.

\begin{tabular}{|c|c|c|c|c|c|c|c|c|c|c|}
\hline & \multirow{3}{*}{$\begin{array}{c}\text { Average }(\mathbf{C U}) \text { in } \\
\text { two seasons } \\
\text { mm/day }\end{array}$} & \multicolumn{9}{|c|}{ Average potential evapotranspiration ( $\mathrm{mm} / \mathrm{day})$ to both } \\
\hline & & \multicolumn{2}{|c|}{$\begin{array}{c}\text { Modified } \\
\text { penman }\end{array}$} & \multicolumn{2}{|c|}{$\begin{array}{c}\text { Modified } \\
\text { Blaney \& } \\
\text { Criddle }\end{array}$} & \multicolumn{2}{|c|}{$\begin{array}{l}\text { Radiation } \\
\text { method }\end{array}$} & \multicolumn{2}{|c|}{ Pan method } & \multirow[t]{2}{*}{$\begin{array}{c}\text { Average } \\
\text { (kc) }\end{array}$} \\
\hline & & mm/day & $\mathbf{K C}$ & $\mathbf{m m} / \mathbf{d a y}$ & KC & $\mathbf{m m} / \mathbf{d a y}$ & KC & $\mathbf{m m} / \mathbf{d a y}$ & KC & \\
\hline Sept. & 2.7 & 8.79 & 0.31 & 6.78 & 0.40 & 7.13 & 0.38 & 4.49 & 0.60 & 0.42 \\
\hline Oct. & 3.5 & 6.72 & 0.52 & 6.01 & 0.58 & 5.86 & 0.60 & 5.23 & 0.67 & 0.59 \\
\hline Nov. & 5.11 & 5.15 & 0.99 & 4.97 & 1.03 & 4.57 & 1.12 & 4.99 & 1.02 & 1.04 \\
\hline Dec. & 2.91 & 4.25 & 0.68 & 4.36 & 0.67 & 3.85 & 0.76 & 4.25 & 0.68 & 0.70 \\
\hline Average & 3.56 & 6.23 & 0.63 & 5.53 & 0.67 & 5.35 & 0.71 & 4.74 & 0.74 & 0.69 \\
\hline \multirow[t]{2}{*}{$\begin{array}{c}\text { Index } \\
\text { Number }\end{array}$} & & & 91.30 & & 94.03 & & 102.90 & & 107.25 & 100.00 \\
\hline & & & 4 & & 1 & & 2 & & 3 & \\
\hline
\end{tabular}

- (CU): Actual consumptive use

Table (18): The crop coefficient $\left(\mathrm{Kc}=\mathrm{ET} / \mathrm{ET}_{\mathrm{p}}\right)$ for treatment $\left(\mathrm{A}_{4} \mathrm{~b}_{2}\right)$ for potato crop in two studied seasons.

\begin{tabular}{|c|c|c|c|c|c|c|c|c|c|c|}
\hline & \multirow{3}{*}{$\begin{array}{c}\text { Average }(\mathrm{CU}) \text { in } \\
\text { two seasons } \\
\mathrm{mm} / \mathrm{day}\end{array}$} & \multicolumn{9}{|c|}{ Average potential evapotranspiration ( $\mathrm{mm} /$ day) to both } \\
\hline & & \multicolumn{2}{|c|}{$\begin{array}{c}\text { Modified } \\
\text { penman }\end{array}$} & \multicolumn{2}{|c|}{$\begin{array}{c}\text { Modified } \\
\text { Blaney \& } \\
\text { Criddle }\end{array}$} & \multicolumn{2}{|c|}{$\begin{array}{l}\text { Radiation } \\
\text { method }\end{array}$} & \multicolumn{2}{|c|}{ Pan method } & \multirow[t]{2}{*}{$\begin{array}{c}\text { Average } \\
\text { (kc) }\end{array}$} \\
\hline & & mm/day & KC & mm/day & KC & mm/day & KC & mm/day & KC & \\
\hline Sept. & 2.77 & 8.79 & 0.32 & 6.78 & 0.41 & 7.13 & 0.39 & 4.49 & 0.62 & 0.43 \\
\hline Oct. & 3.54 & 6.72 & 0.53 & 6.01 & 0.59 & 5.86 & 0.60 & 5.23 & 0.68 & 0.60 \\
\hline Nov. & 5.16 & 5.15 & 1.00 & 4.97 & 1.04 & 4.57 & 1.13 & 4.99 & 1.03 & 1.05 \\
\hline Dec. & 2.98 & 4.25 & 0.70 & 4.36 & 0.68 & 3.85 & 0.77 & 4.25 & 0.70 & 0.71 \\
\hline Average & 3.61 & 6.23 & 0.64 & 5.53 & 0.68 & 5.35 & 0.72 & 4.74 & 0.76 & 0.70 \\
\hline \multirow[t]{2}{*}{$\begin{array}{c}\text { Index } \\
\text { Number }\end{array}$} & & & 91.43 & & 97.14 & & 102.86 & & 108.57 & 100.00 \\
\hline & & & 4 & & 1 & & 2 & & 3 & \\
\hline
\end{tabular}

- (CU): Actual consumptive use

Table (19): The crop coefficient $\left(\mathrm{Kc}=\mathrm{ET} \mathrm{a}_{\mathrm{a}} / \mathbf{E T} \mathrm{T}_{\mathrm{p}}\right)$ for treatment $\left(\mathrm{A}_{4} \mathrm{~b}_{3}\right)$ for potato crop in two studied seasons.

\begin{tabular}{|c|c|c|c|c|c|c|c|c|c|c|}
\hline & \multirow{3}{*}{$\begin{array}{c}\text { Average }(\mathbf{C U}) \text { in } \\
\text { two seasons } \\
\text { mm/day }\end{array}$} & \multicolumn{9}{|c|}{ Average potential evapotranspiration ( $\mathrm{mm} / \mathrm{day})$ to both } \\
\hline & & \multicolumn{2}{|c|}{$\begin{array}{l}\text { Modified } \\
\text { penman }\end{array}$} & \multicolumn{2}{|c|}{$\begin{array}{c}\text { Modified } \\
\text { Blaney \& } \\
\text { Criddle }\end{array}$} & \multicolumn{2}{|c|}{$\begin{array}{l}\text { Radiation } \\
\text { method }\end{array}$} & \multicolumn{2}{|c|}{ Pan method } & \multirow[t]{2}{*}{$\begin{array}{c}\text { Average } \\
\text { (kc) }\end{array}$} \\
\hline & & mm/day & KC & mm/day & KC & mm/day & KC & mm/day & KC & \\
\hline Sept & 2.51 & 8.79 & 0.29 & 6.78 & 0.37 & 7.13 & 0.35 & 4.49 & 0.56 & 0.39 \\
\hline Oct. & 3.37 & 6.72 & 0.50 & 6.01 & 0.56 & 5.86 & 0.58 & 5.23 & 0.64 & 0.57 \\
\hline Nov. & 5.25 & 5.15 & 1.02 & 4.97 & 1.06 & 4.57 & 1.15 & 4.99 & 1.05 & 1.07 \\
\hline Dec. & 2.72 & 4.25 & 0.64 & 4.36 & 0.62 & 3.85 & 0.71 & 4.25 & 0.64 & 0.65 \\
\hline Average & 3.46 & 6.23 & 0.61 & 5.53 & 0.65 & 5.35 & 0.70 & 4.74 & 0.72 & 0.67 \\
\hline \multirow[t]{2}{*}{$\begin{array}{c}\text { Index } \\
\text { Number }\end{array}$} & & & 91.04 & & 97.01 & & 104.48 & & 107.46 & 100.00 \\
\hline & & & 4 & & 1 & & 2 & & 3 & \\
\hline
\end{tabular}

- $\quad(C U):$ Actual consumptive use 
2- Calculated crop coefficient for potato crop under different irrigation regimes

Table (20): The crop coefficient $\left(\mathrm{Kc}=\mathrm{ET} \mathrm{a}_{\mathrm{a}} / \mathrm{ET} \mathrm{T}_{\mathrm{p}}\right)$ for treatment $\left(\mathrm{A}_{4} \mathrm{~b}_{4}\right)$ for potato crop in two studied seasons.

\begin{tabular}{|c|c|c|c|c|c|c|c|c|c|c|}
\hline & \multirow{3}{*}{$\begin{array}{c}\text { Average }(\mathrm{CU}) \text { in } \\
\text { two seasons } \\
\mathrm{mm} / \mathrm{day}\end{array}$} & \multicolumn{9}{|c|}{ Average potential evapotranspiration $(\mathrm{mm} / \mathrm{day})$ to both } \\
\hline & & \multicolumn{2}{|c|}{$\begin{array}{l}\text { Modified } \\
\text { penman }\end{array}$} & \multicolumn{2}{|c|}{$\begin{array}{c}\text { Modified } \\
\text { Blaney \& } \\
\text { Criddle }\end{array}$} & \multicolumn{2}{|c|}{$\begin{array}{l}\text { Radiation } \\
\text { method }\end{array}$} & \multicolumn{2}{|c|}{ Pan method } & \multirow[t]{2}{*}{$\begin{array}{c}\text { Average } \\
\text { (kc) }\end{array}$} \\
\hline & & mm/day & KC & mm/day & KC & mm/day & KC & mm/day & KC & \\
\hline Sept & 2.92 & 8.79 & 0.33 & 6.78 & 0.43 & 7.13 & 0.41 & 4.49 & 0.65 & 0.46 \\
\hline Oct. & 3.65 & 6.72 & 0.54 & 6.01 & 0.61 & 5.86 & 0.62 & 5.23 & 0.70 & 0.62 \\
\hline Nov. & 5.27 & 5.15 & 1.02 & 4.97 & 1.06 & 4.57 & 1.15 & 4.99 & 1.06 & 1.07 \\
\hline Dec. & 3.13 & 4.25 & 0.74 & 4.36 & 0.72 & 3.85 & 0.81 & 4.25 & 0.74 & 0.75 \\
\hline Average & 3.74 & 6.23 & 0.66 & 5.53 & 0.70 & 5.35 & 0.75 & 4.74 & 0.79 & 0.72 \\
\hline \multirow[t]{2}{*}{$\begin{array}{c}\text { Index } \\
\text { Number }\end{array}$} & & & 91.67 & & 97.22 & & 104.17 & & 109.72 & 100.00 \\
\hline & & & 4 & & 1 & & 2 & & 3 & \\
\hline
\end{tabular}

- $\quad(C U):$ Actual consumptive use

Table (21): The crop coefficient $\left(\mathrm{Kc}=\mathrm{ET} \mathrm{a}_{\mathrm{a}} / \mathrm{ET} \mathrm{T}_{\mathrm{p}}\right)$ for treatment $\left(\mathrm{A}_{5} \mathrm{~b}_{1}\right)$ for potato crop in two studied seasons.

\begin{tabular}{|c|c|c|c|c|c|c|c|c|c|c|}
\hline & \multirow{3}{*}{$\begin{array}{c}\begin{array}{c}\text { Average }(\mathrm{CU}) \text { in } \\
\text { two seasons }\end{array} \\
\mathrm{mm} / \text { day }\end{array}$} & \multicolumn{9}{|c|}{ Average potential evapotranspiration ( $\mathrm{mm} /$ day) to both } \\
\hline & & \multicolumn{2}{|c|}{$\begin{array}{l}\text { Modified } \\
\text { penman }\end{array}$} & \multicolumn{2}{|c|}{$\begin{array}{c}\text { Modified } \\
\text { Blaney \& } \\
\text { Criddle } \\
\end{array}$} & \multicolumn{2}{|c|}{$\begin{array}{l}\text { Radiation } \\
\text { method }\end{array}$} & \multicolumn{2}{|c|}{ Pan method } & \multirow[t]{2}{*}{$\begin{array}{c}\text { Average } \\
\text { (kc) }\end{array}$} \\
\hline & & mm/day & KC & mm/day & KC & $\mathbf{m m} / \mathbf{d a y}$ & KC & mm/day & KC & \\
\hline Sept & 2.6 & 8.79 & 0.30 & 6.78 & 0.38 & 7.13 & 0.36 & 4.49 & 0.58 & 0.41 \\
\hline Oct. & 3.43 & 6.72 & 0.51 & 6.01 & 0.57 & 5.86 & 0.59 & 5.23 & 0.66 & 0.58 \\
\hline Nov. & 5.05 & 5.15 & 0.98 & 4.97 & 1.02 & 4.57 & 1.11 & 4.99 & 1.01 & 1.03 \\
\hline Dec. & 2.8 & 4.25 & 0.66 & 4.36 & 0.64 & 3.85 & 0.73 & 4.25 & 0.66 & 0.67 \\
\hline Average & 3.47 & 6.23 & 0.61 & 5.53 & 0.65 & 5.35 & 0.70 & 4.74 & 0.73 & 0.67 \\
\hline \multirow[t]{2}{*}{$\begin{array}{c}\text { Index } \\
\text { Number }\end{array}$} & & & 87.14 & & 97.01 & & 104.48 & & 108.96 & 100.00 \\
\hline & & & 4 & & 1 & & 2 & & 3 & \\
\hline
\end{tabular}

- $(C U):$ Actual consumptive use

Table (22): The crop coefficient $\left(\mathrm{Kc}=\mathrm{ET} \mathrm{a}_{\mathrm{a}} / \mathrm{ET} \mathrm{T}_{\mathrm{p}}\right)$ fortreatment $\left(\mathrm{A}_{5} \mathrm{~b}_{2}\right)$ for potato crop in two studied seasons.

\begin{tabular}{|c|c|c|c|c|c|c|c|c|c|c|}
\hline & \multirow{3}{*}{$\begin{array}{c}\begin{array}{c}\text { Average }(\mathrm{CU}) \text { in } \\
\text { two seasons }\end{array} \\
\mathrm{mm} / \mathrm{day}\end{array}$} & \multicolumn{9}{|c|}{ Average potential evapotranspiration $(\mathrm{mm} /$ day $)$ to both } \\
\hline & & \multicolumn{2}{|c|}{$\begin{array}{l}\text { Modified } \\
\text { penman }\end{array}$} & \multicolumn{2}{|c|}{$\begin{array}{c}\text { Modified } \\
\text { Blaney \& } \\
\text { Criddle } \\
\end{array}$} & \multicolumn{2}{|c|}{$\begin{array}{l}\text { Radiation } \\
\text { method }\end{array}$} & \multicolumn{2}{|c|}{ Pan method } & \multirow[t]{2}{*}{$\begin{array}{c}\text { Average } \\
\text { (kc) }\end{array}$} \\
\hline & & $\mathbf{m m} /$ day & KC & mm/day & KC & mm/day & KC & $\mathbf{m m} /$ day & KC & \\
\hline Sept & 2.67 & 8.79 & 0.30 & 6.78 & 0.39 & 7.13 & 0.37 & 4.49 & 0.59 & 0.42 \\
\hline Oct. & 3.47 & 6.72 & 0.52 & 6.01 & 0.58 & 5.86 & 0.59 & 5.23 & 0.66 & 0.59 \\
\hline Nov. & 5.09 & 5.15 & 0.99 & 4.97 & 1.02 & 4.57 & 1.11 & 4.99 & 1.02 & 1.04 \\
\hline Dec. & 2.88 & 4.25 & 0.68 & 4.36 & 0.66 & 3.85 & 0.75 & 4.25 & 0.68 & 0.69 \\
\hline Average & 3.53 & 6.23 & 0.62 & 5.53 & 0.66 & 5.35 & 0.71 & 4.74 & 0.74 & 0.68 \\
\hline \multirow[t]{2}{*}{$\begin{array}{c}\text { Index } \\
\text { Number }\end{array}$} & & & 91.18 & & 97.06 & & 104.41 & & 108.82 & 100.00 \\
\hline & & & 4 & & 1 & & 2 & & 3 & \\
\hline
\end{tabular}


Abdel-Ati Y.Y. et al.

Table (23): The crop coefficient $\left(\mathrm{Kc}=\mathrm{ET} \mathrm{a}_{\mathrm{a}} / \mathbf{E T} \mathrm{T}_{\mathrm{p}}\right)$ for treatment $\left(\mathrm{A}_{5} \mathrm{~b}_{3}\right)$ for potato crop in two studied seasons.

\begin{tabular}{|c|c|c|c|c|c|c|c|c|c|c|}
\hline & \multirow{3}{*}{$\begin{array}{c}\begin{array}{c}\text { Average }(\mathrm{CU}) \text { in } \\
\text { two seasons }\end{array} \\
\mathrm{mm} / \mathrm{day}\end{array}$} & \multicolumn{9}{|c|}{ Average potential evapotranspiration $(\mathrm{mm} / \mathrm{day})$ to both } \\
\hline & & \multicolumn{2}{|c|}{$\begin{array}{c}\text { Modified } \\
\text { penman }\end{array}$} & \multicolumn{2}{|c|}{$\begin{array}{c}\text { Modified } \\
\text { Blaney \& } \\
\text { Criddle }\end{array}$} & \multicolumn{2}{|c|}{$\begin{array}{l}\text { Radiation } \\
\text { method }\end{array}$} & \multicolumn{2}{|c|}{ Pan method } & \multirow[t]{2}{*}{$\begin{array}{c}\text { Average } \\
\text { (kc) }\end{array}$} \\
\hline & & mm/day & $\mathbf{K C}$ & mm/day & KC & mm/day & KC & mm/day & KC & \\
\hline Sept & 2.5 & 8.79 & 0.28 & 6.78 & 0.37 & 7.13 & 0.35 & 4.49 & 0.56 & 0.39 \\
\hline Oct. & 3.36 & 6.72 & 0.50 & 6.01 & 0.56 & 5.86 & 0.57 & 5.23 & 0.64 & 0.57 \\
\hline Nov. & 4.98 & 5.15 & 0.97 & 4.97 & 1.00 & 4.57 & 1.09 & 4.99 & 1.00 & 1.01 \\
\hline Dec. & 2.7 & 4.25 & 0.64 & 4.36 & 0.62 & 3.85 & 0.70 & 4.25 & 0.64 & 0.65 \\
\hline Average & 3.39 & 6.23 & 0.60 & 5.53 & 0.64 & 5.35 & 0.68 & 4.74 & 0.71 & 0.66 \\
\hline \multirow[t]{2}{*}{$\begin{array}{l}\text { Index } \\
\text { Number }\end{array}$} & & & 90.91 & & 96.97 & & 10.03 & & 10.58 & 100.00 \\
\hline & & & 4 & & 1 & & 2 & & 3 & \\
\hline
\end{tabular}

- (CU): Actual consumptive use

Table (24): The crop coefficient $\left(\mathrm{Kc}=\mathrm{ET} \mathrm{a}_{\mathrm{a}} / \mathrm{ET} \mathrm{T}_{\mathrm{p}}\right)$ for treatment $\left(\mathrm{A}_{5} \mathrm{~b}_{4}\right)$ for potato crop in two studied seasons.

\begin{tabular}{|c|c|c|c|c|c|c|c|c|c|c|}
\hline & \multirow{3}{*}{$\begin{array}{c}\text { Average }(\mathbf{C U}) \text { in } \\
\text { two seasons } \\
\text { mm/day }\end{array}$} & \multicolumn{9}{|c|}{ Average potential evapotranspiration $(\mathrm{mm} / \mathrm{day})$ to both } \\
\hline & & \multicolumn{2}{|c|}{$\begin{array}{c}\text { Modified } \\
\text { penman }\end{array}$} & \multicolumn{2}{|c|}{$\begin{array}{c}\text { Modified } \\
\text { Blaney \& } \\
\text { Criddle }\end{array}$} & \multicolumn{2}{|c|}{$\begin{array}{l}\text { Radiation } \\
\text { method }\end{array}$} & \multicolumn{2}{|c|}{ Pan method } & \multirow[t]{2}{*}{$\begin{array}{c}\text { Average } \\
\text { (kc) }\end{array}$} \\
\hline & & mm/day & $\mathrm{KC}$ & mm/day & $\mathrm{KC}$ & mm/day & $\mathrm{KC}$ & mm/day & $\mathrm{KC}$ & \\
\hline Sept & 2.81 & 8.79 & 0.32 & 6.78 & 0.41 & 7.13 & 0.39 & 4.49 & 0.63 & 0.44 \\
\hline Oct. & 3.57 & 6.72 & 0.53 & 6.01 & 0.59 & 5.86 & 0.61 & 5.23 & 0.68 & 0.60 \\
\hline Nov. & 5.19 & 5.15 & 1.01 & 4.97 & 1.04 & 4.57 & 1.14 & 4.99 & 1.04 & 1.06 \\
\hline Dec. & 3.03 & 4.25 & 0.71 & 4.36 & 0.69 & 3.85 & 0.79 & 4.25 & 0.71 & 0.73 \\
\hline Average & 3.65 & 6.23 & 0.64 & 5.53 & 0.69 & 5.35 & 0.73 & 4.74 & 0.77 & 0.71 \\
\hline \multirow[t]{2}{*}{$\begin{array}{c}\text { Index } \\
\text { Number }\end{array}$} & & & 90.14 & & 97.18 & & 102.82 & & 108.45 & 100.00 \\
\hline & & & 4 & & 1 & & 2 & & 3 & \\
\hline
\end{tabular}

- $\quad(C U):$ Actual consumptive use

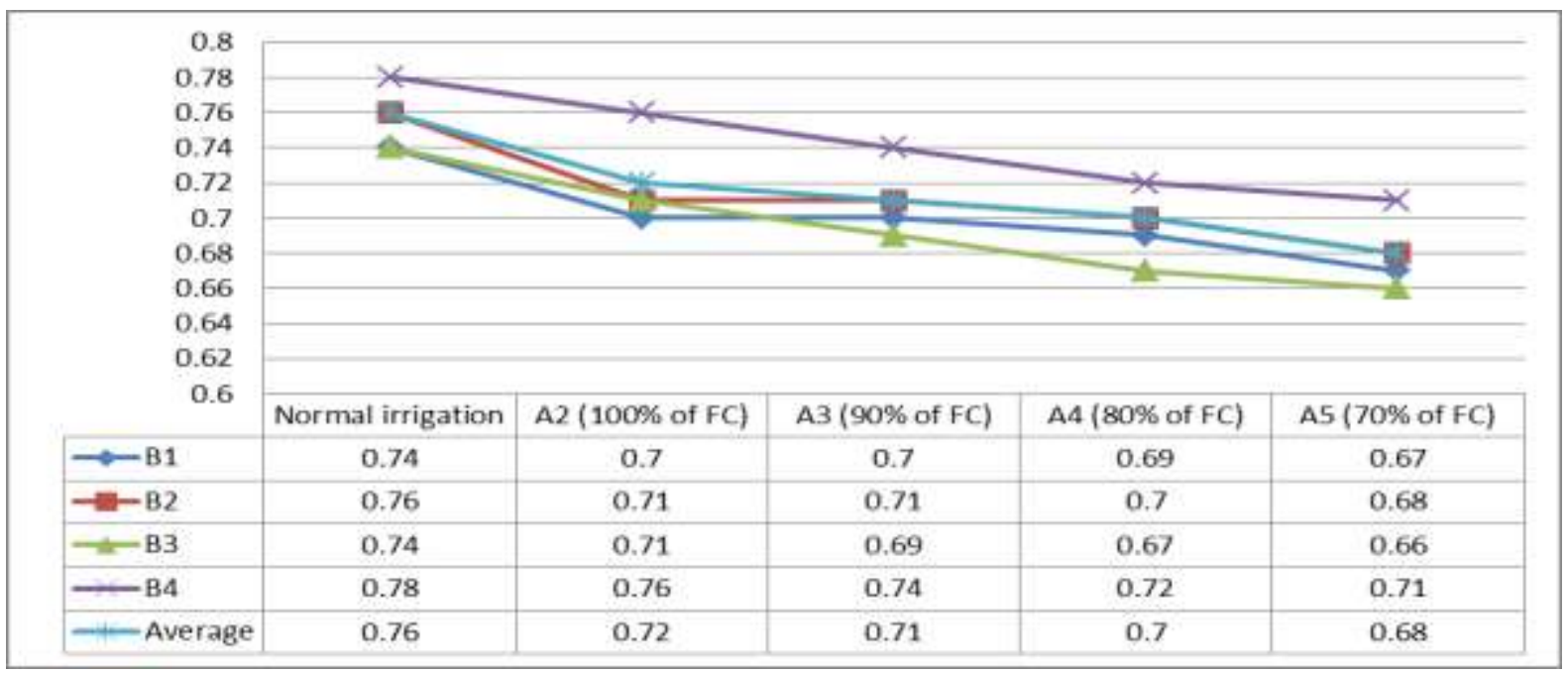

Fig (1): The average of crop coefficient $\left(\mathrm{Kc}=\mathrm{ET}_{\mathrm{a}} / \mathrm{ET}_{\mathrm{p}}\right)$ for potato crop in two studied seasons. 
2- Calculated crop coefficient for potato crop under different irrigation regimes

Table (25): Comparison between the actual consumptive use $(\mathrm{cm} / \mathrm{season}$ for two seasons) and calculated evapotranspiration $(\mathrm{cm} / \mathrm{season}$ for two season) for different irrigation treatments for potato crop.

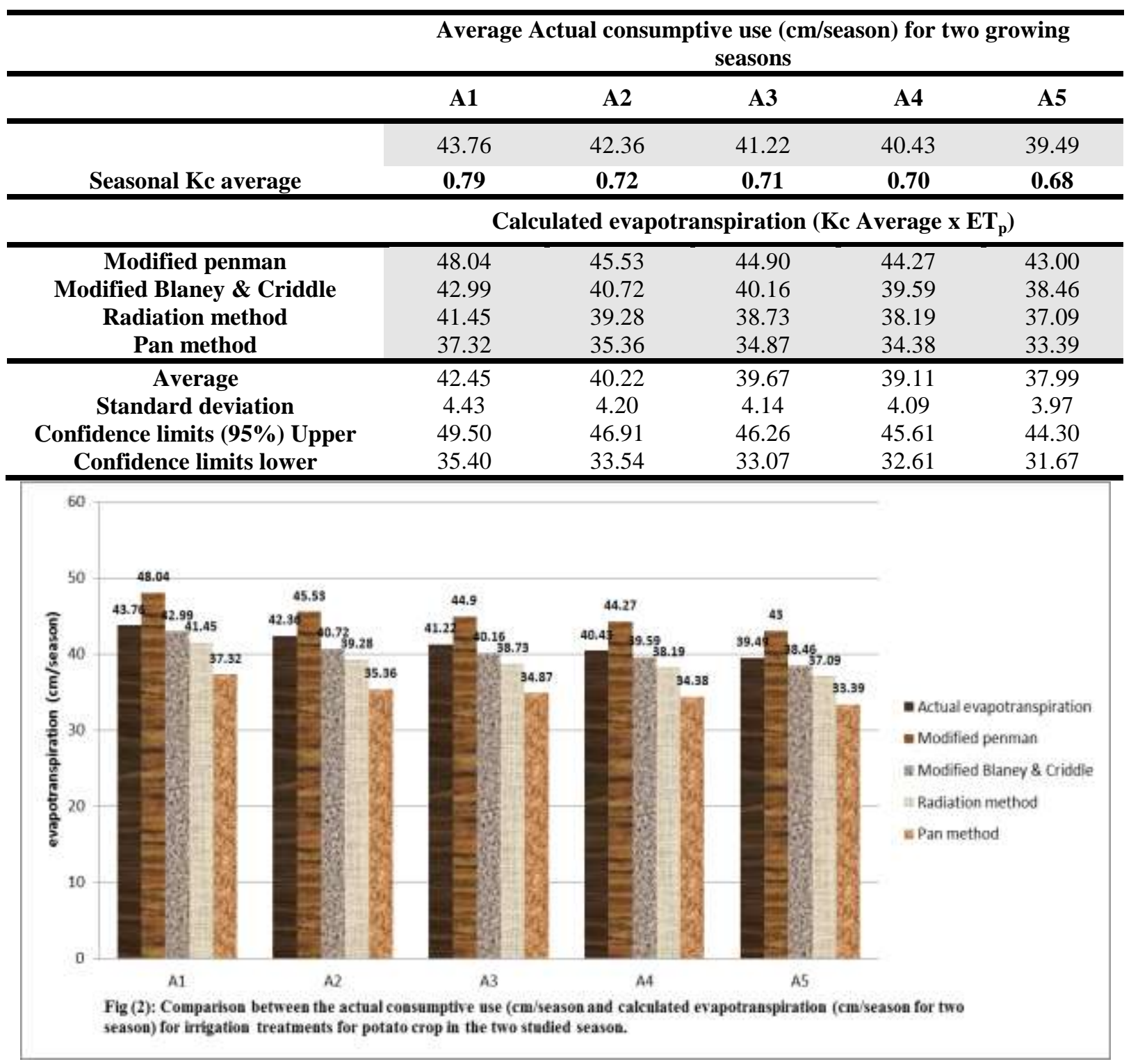

\section{CONCLUSION}

The values of crop coefficient average (Kc average) by many empirical formulae were 0.76, 0.72, $0.71,0.70$ and 0.68 for $A_{1}, A_{2}, A_{3}, A_{4}$ and $A_{5}$ under all semi treatmenets $b_{1}, b_{2}, b_{3}$ and $b_{4}$, respectively. Radiation method and modified Blaney \& Criddle were nearest to actual consumptive use. So, the author recommends using modified Blaney \& Criddle or radiation method for calculating the potential evapotranspiration for potato plants which grow under El-Minia conditions and other corresponding conditions. 
Abdel-Ati Y.Y. et al.

\section{REFERENCES}

Abdel-Mottaleb, F.A. (1987). Physiological studies on the water requirements of corn plant "Zea Maize". Ph.D. Thesis, Fac. of Agric. Moshtoher, Zagazig Univ.

Abubaker, B.M.A.; Shuang-En,Y.; Guang-Cheng, S.; Alhadi, M. and Elsiddig, A. (2014). Effect of irrigation levels on the growth, yield and quality of potato. Bulgarian Journal of Agricultural Science, 20 (2): 303-309.

Ali, M. A. (1993). Physiological studies on water requirements of potato plant. Ph. D. Thesis. Fac. Agric. Moshtohor, Zagazig Univ, Egypt.

Allen, R.G.; Periera L.S.; Raes D. and Smith M. (1998). Crop evapotranspiration: Guidelines for computing crop requirements. Irrigation and Drainage paper No.56, FAO, Rome. Italy, 300pp.

Black, C.A. (1965). Methods of Soil Analysis. Amer. Soc. of Agron. Inc., Madison, Wisconsin, USA.

Blaney, H.F. and Criddle W.D. (1955). Determining water in irrigated areas from climatological and irrigation data, SCS-TP-46, Soil conservation service, U.S. Department of Agriculture, Washington.

Daniel, F.C.; Dione, G.S.; Hermes, S.R.; Wilk, S.A and Eraldo, S.S. (2013). Evapotranspration and crop coefficient for potato crop in orgamic farming. Eng. Agric., Jaboticabal,33(I):201-211.

Doorenbos, J. and Pruitt, W.O. (1975). Crop water requirements. Irrigation and Drainage paper 24, F.A.O Rome.

Doorenbos, J. and Pruitt, W.D. (1977). Guidelines for predicting crop water requirements. F.A.O. Irrigation and Drainage paper No. 24, (revised) FAO, Rome, Italy.

Doorenbos, J. and Kassam A. H. (1986). Yield response to water. Irrigation and Drainage. Paper No. 33, FAO, Rome, Italy.

Eid, H.M.; Ainer, N.G.; and Metwally, M.A. (1987). Estimation of irrigation and temperature needs for the new land in Egypt. Mansoura Univ. Conf. of Agric. Sci. on Food Deficiency over Coming through Autonomous Efforts in Egypt 22-24 June, 1987.

El-Naggar, E.M. I. (1997). Consumptive use under drip irrigation system M.Sc. Thesis. Dept. of Soil Science, Fac. of Agric., Ain Shams University.

El-Tantawy F.A. and Manal, M.M. (1997). Plant response to climatic factors as an indication to estimating evapotranspiration for some vegetable crops. Ph. D. Thesis, Fac. Agric., Ain Shams Univ.

F.A.O. (1977). Crop water requirements. Irrigation and drainage paper 24. Food and Agriculture Organization for the United Nations, Romw revised, 1977.

Ferdous, A.; Onawi, I. and Shatanawi, M. (1985). Determination of crop coefficient for potatoes in the Jordan valley, Amman (Jordan). 18 p. (C.f. AGRIS 1986-1988).

Gething, P.A. (1997). Potash Facts. IPI Henely-on-Thames, United Kingdom. (C.f. Arabic translation by Negm, A.Y; A.H. Abdel-Hadi and M.S. Khadr, 1997). SWERI, ARC. Egypt.

Israelsen, O. W. and Hansen, V. E. (1962). Irrigation principles and practices. 3rd Edit. John willey \& Sons. Inc., New York.

Khalak, A. and Kumaraswamy, A.S. (1996). Water use efficiency and nutrient uptake in potato. Mysora J. Agric. Sci., 30(1): 39-42.

Klute, A. (1986). Methods of soil analysis. Part 1: Physical and mineralogical melhods (2nd ed.). American Society of Agron Madison Wisconsin. U.S.A.

Omar, M.H. and Eid, H.M. (1999). Comparative study on ETo estimated with different ET formulae in South Delta. Third Conference of On-Farm Irrigation and Agrocilmatology (under publication). 


\section{Improvement of water use efficiency on potato production 2- Calculated crop coefficient for potato crop under different irrigation regimes}

Oweis, T. Y.; Ghawi, I. O. and Shatanawi, M. R. (1988). Irrigation production function and crop coefficients of potato in the Jordan Valley. Dirasat 15 (10): 43-55.

Penman, H. L. (1961). Weather, plant and soil factors in hydrology Weather, 16, 207.

Rijtema, P.E. (1966). Transpiration and production of crops in relation to climate and irrigation. Institute Land and Water Mangement Research Holland (C.f A.F.M. Mohamed (1981) Ph.D Thesis Fac. Agric. Alex.).

Sahin, U., Kiziloglu, F. M.; Anapali, O. and Okuroglu., M. (2007). Determining crop and pan coefficients for sugarbeet and potato crops under cool season semiarid climatic conditions. J. Agronomy and Crop Science 193(2):146-152.

Semaika, M.A. (1987). On the calculation of crop coefficient when estimatiny crop water requirement. Water science 3 rd Issue, 2 nd year, November 1987- Egypt.

Stansell, J.R.; Hall, M.R. and Smittle, D.A. (1990). Effects of irrigation regimes on yield and water use by sweet potato. J. Am. Socicty for Horticultural Seience, Goshbs. 115 (5): 712-714.

Van der Molen, (1976). Agrohydrology. M.Sc. Course in soil science and water management, Agric Univ. Wageningon-Holland (C.f. M (1981) Ph.D. Thesis, Fac. Agric., Alexandria.

Vermiren, L. and Jobling, G. A. (1986). Localized irrigation: design installation, Operation and evaluation. Irrigation and Drainage Paper No. 36, FAO, Rome, Italy.

Wright, J.L. (1981). Crop coefficients for estimates of daily evapotranspiration. Proc. American Society of Agricultural Engineers. Irrigation Scheduling Conference, St. Joseph, MI. pp18-26. 


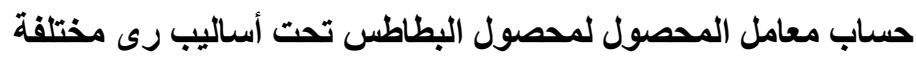

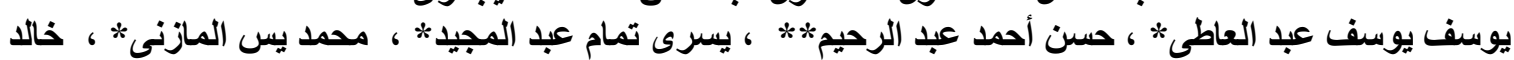

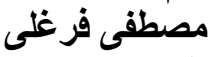

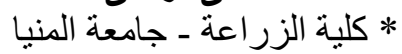

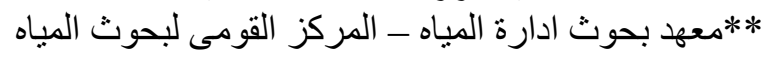

المستخلص المر ماه

أجريت تجربتين حقليتين خلال المو اسم الزر اعيه لعامى 2012 ، 2013م بمحطة مقننات رعى ملوى البحثيه التابعه

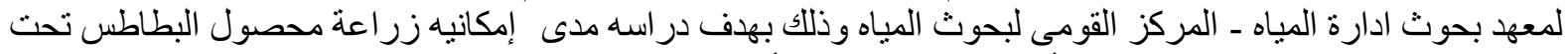

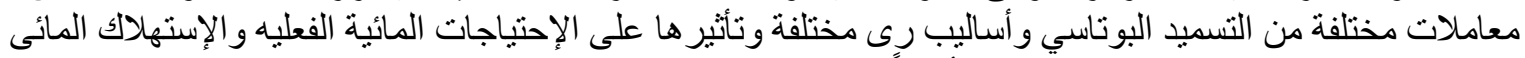

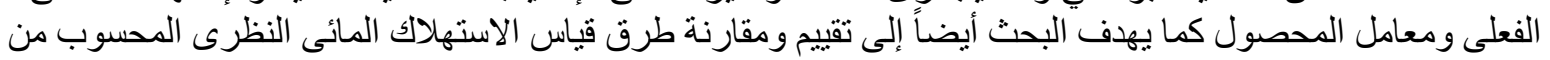

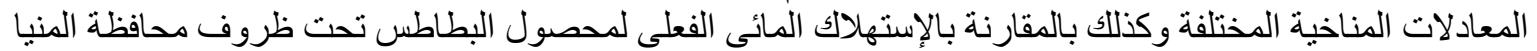

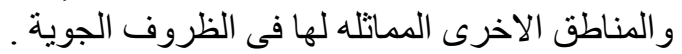

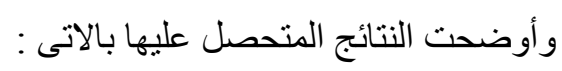

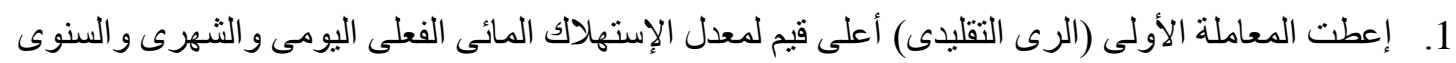

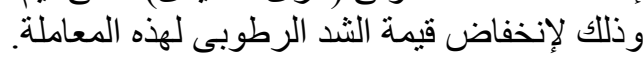

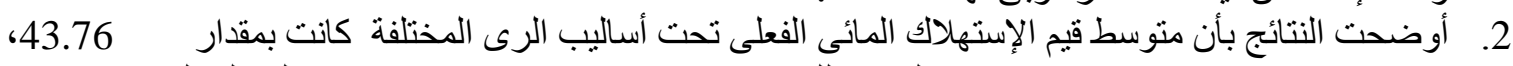

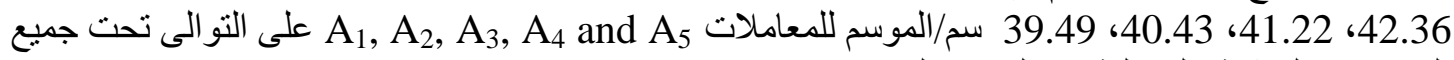

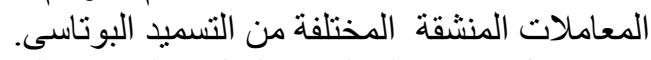

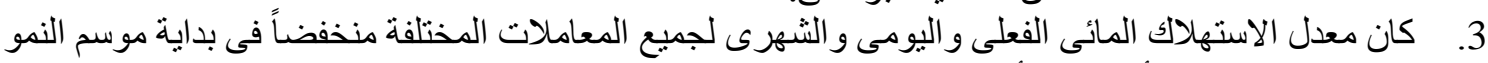

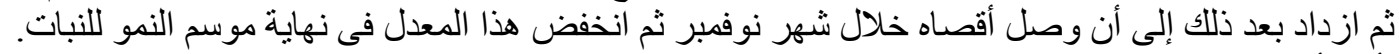

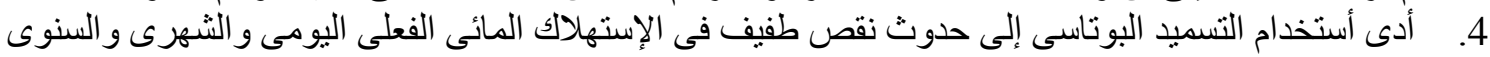

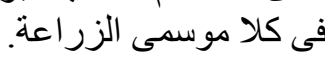
5. أعطت معادلة بنمان المعدلة وبلاني وكرديل المعدلة أعلى القيم من البخر ـ النتح بمعدل 63.24 سم/موسم خلال

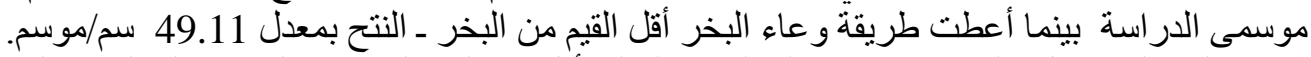

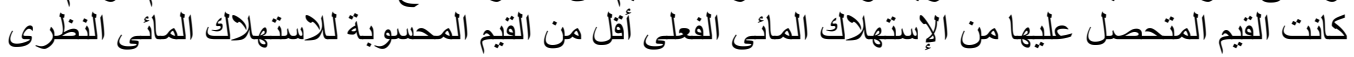

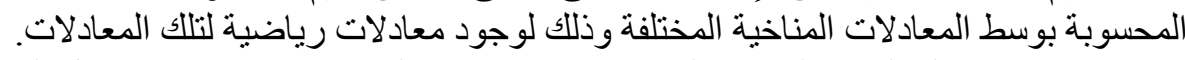

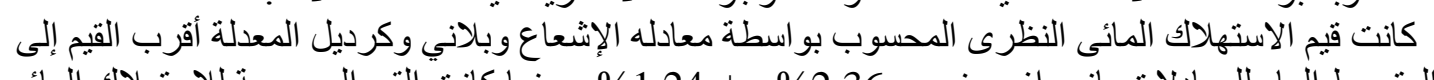

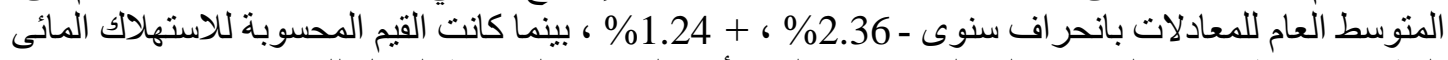

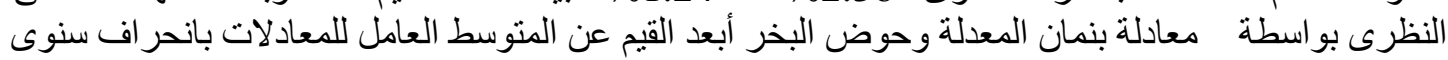

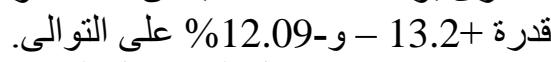

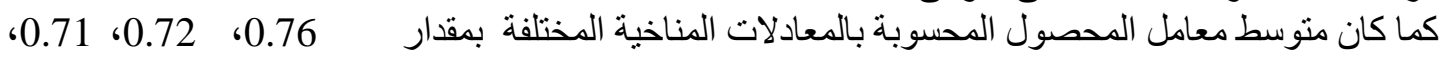

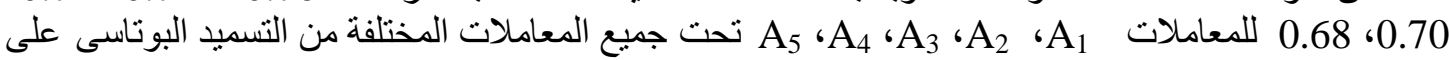

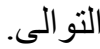

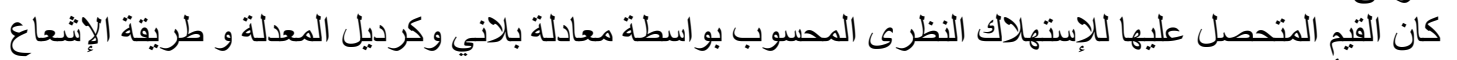

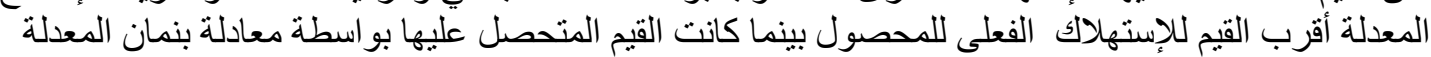

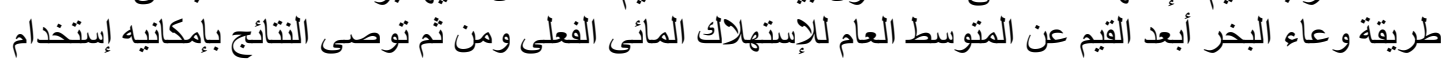

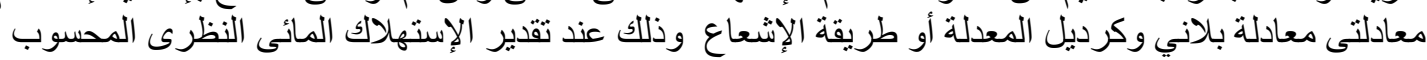

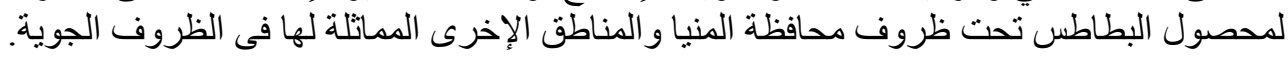

